\title{
ESTUDO CLÍNICO E RADIOGRÁFICO DE DENTES AVULSIONADOS ACIDENTALMENTE E REIMPLANTADOS RETROSPECTIVA DE 18 ANOS
}

JOSE NETO DA COSTA

Dissertação apresentada à Faculdade de Odontologia de Bauru, da Universidade de São Paulo, como parte dos requisitos para obtenção do título de Mestre em Odontologia, área de Endodontia.

(Edição Revisada)

Orientador: Prof. Dr. Roberto Brandão Garcia 
Costa, Jose Neto da

C823e Estudo clínico e radiográfico de dentes avulsionados acidentalmente e reimplantados. Retrospectiva de 18 anos / Jose Neto da Costa - Bauru, 2002;

107 p.: il.; $9 \mathrm{~cm}$.

Dissertação. (Mestrado) — Faculdade de Odontologia de Bauru. Universidade de São Paulo.

Orientador: Prof. Dr. Roberto Brandão Garcia

Autorizo, exlusivamente para fins acadêmicos e científicos, a reprodução total ou parcial desta dissertação, por processos fotocopiadores e outros meios eletrônicos.

Autor:

Data:

/ 1


11 de março de 1956

Conceição do Canindé-PI

$1979-1982$

$1990-2000$

$1997-2002$

$2000-2002$
Nascimento

Curso de Graduação em Odontologia Faculdade de Odontologia de Bauru Universidade de São Paulo.

Cirurgião-Dentista do Serviço de Urgência Odontológica da Faculdade de Odontologia de Bauru Universidade de São Paulo.

Curso de Pós- Graduação em Endodontia, em nível de Mestrado, na Faculdade de Odontologia de Bauru Universidade de São Paulo.

Professor de Endodontia do Curso de Odontologia - Universidade Estadual do Oeste do Paraná - UNIOESTE. 


\section{Dedicatória}


Ao meu filho Nikolas, principal catalisador de todas as minhas aspirações, meu obrigado a Deus por tê-lo na minha vida,

Ao meu pai Gonçalo e minha mãe Maria, motivos de orgulho maior em toda a minha vida, agradeço a dedicação, carinho e amor que sempre estiveram presentes em todos os seus atos. Tenham certeza que nada disto faria sentido se eu não pudesse mostrar a vocês.

A minha querida esposa Joana D'Arc, pelo apoio, ternura, companheirismo e renúncia dedicados a mim, principalmente pela sua compreensão e paciência nos momentos que estive ausente durante a elaboração deste trabalho.

Aos meus irmãos Cido, Moacir, Juarez $e$ minha cunhada Ana Lúcia, que sempre demonstraram carinho e respeito pelo meu trabalho 


\section{Agradecimento Especial}

Ao meu orientador, Prof. Dr. Roberto Brandão

Garcia, fonte inesgotável de vitalidade, dedicação ao trabalho e seriedade profissional, foi um privilégio ímpar de tê-lo como orientador durante a execução deste trabalho. Com o Sr. aprendi não somente ciência, mas principalmente que a humildade é a maior virtude de um homem. Tenho certeza que cada ato seu servirá de modelo para minha vida profissional e humana. Sem a sua humildade e compreensão eu não teria chegado ao final desta longa caminhada, gostaria muito de poder retribuir toda sua generosidade...........porém, não terei nunca como fazê-lo, só me restando desejar que pessoas com a sua índole sejam uma constante no caminho de teus entes mais queridos................que Deus lhe abençõe !! 
Aos Professores da Disciplina de Endodontia Dr. Alceu Berbert, Dr. Clóvis Monteiro Bramante, Dr. Ivaldo Gomes de Moraes e Dr. Norberti Bernardineli, pela convivência nestes anos, pelos ensinamentos e pela amizade.

Agradeço de maneira especial ao Prof. Dr. José Humberto Damante, um Professor, amigo e conselheiro, cuja personalidade aprendi a admirar e respeitar durante a convivência no Serviço de Urgência Odontológica. Meu muito obrigado pelo constante incentivo na carreira e, o otimismo com que me fez ver a profissão de professor.

Ao Prof. Dr. José Carlos Pereira, sinônimo de sinceridade e compreensão, a minha eterna gratidão. 
Agradeço ainda,

A todos os professores desta casa de ensino que, no cumprimento de seus deveres, participaram da minha formação;

Aos funcionários do Departamento de Endodontia, Edimauro, Suely, Neide, Cleide e Patrícia;

Aos colegas e amigos do Curso de Mestrado em Endodontia: Christian, Cláudio, Flaviana, Luciana, Narumi, Patrícia e Sérgio, que concederam-me suas amizades $e$ colaboração durante o curso e também pelos momentos de alegria que passamos, suplantando as dificuldades que surgiram e que deixarão saudades eternamente;

Aos funcionários do Seriço de Urgência Odontológica: Alice, Elza, Regina, Maria, Silvia, Tania e Christiano, que sempre mostraram-se dispostos a me acolher $e$ me ajudar, dispensando atenção, carinho e amizade;

Aos funcionários da Seção de Pós-graduação:

Neide, Heloisa, Giane, Débora, Ana Maria, Cleusa, Aurélio, pelo apoio e atenção;

Aos funcionários da Biblioteca da Faculdade de Odontologia de Bauru-USP, Cybelle, Rita, Vera, Tereza, Tamara, Maria Helena, Valéria, Marcelo, Mônica, César, Jane, 
Ana Paula, Eliane, Denise, Ademir, Maria Otília, Brejão, Salvador e André;

Aos Professores do Curso de Pós-graduação pelo muito que contribuíram à minha formação;

Aos pacientes pertencentes à mostra deste estudo, imprescindíveis para a realização do mesmo;

À Faculdade de Odontologia de Bauru da Universidade de São Paulo, representada pela Diretora, Profa. Dra. Maria Fidela de Lima Navarro;

E a todos, que de uma forma ou outra, me auxiliaram nesta caminhada,

O meu muito obrigado!! 


\section{SUMÁRIO}

LISTA DE FIGURAS

LISTA DE TABELAS................................................................ xii

RESUMO

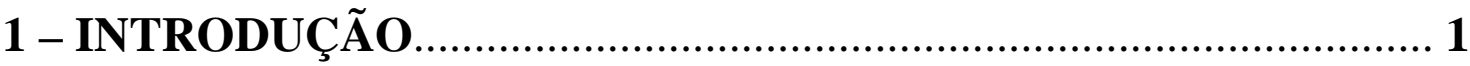

2 - REVISÃO DE LITERATURA.............................................. 8

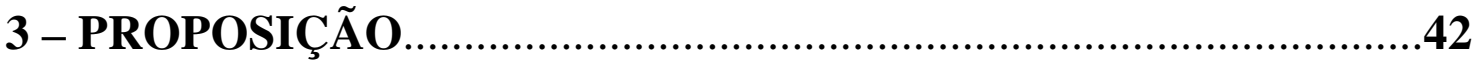

4 - MATERIAL E MÉTODOS.................................................. 44

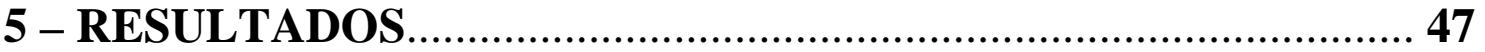

5.1 -Tratamentos iniciais............................................................. 48

Tempo de permanência extra-alveolar ....................................... 48

Meio usado na conservação do dente ............................................ 49

Preparo do alvéolo ............................................................. 49

Tratamento da superfície radicular ...................................... 49

Tipos de contenção empregados ................................................ 50

Medicação sistêmica .......................................................... 50

5.2 - Proservação instituída ........................................................51

5.3 - Dados epidemiológicos .......................................................... 51

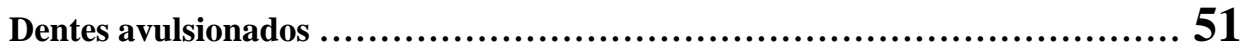

Idade dos pacientes na avulsão ........................................... 52

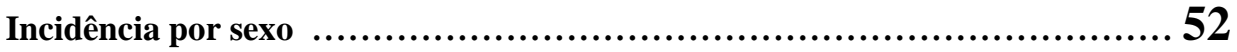

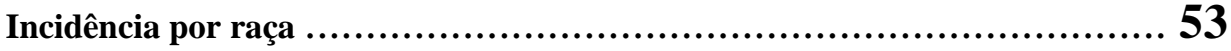

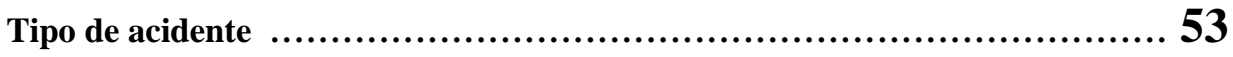

Ambiente de ocorrência

Distribuição dos pacientes no período analisado ............................... 54

Número de dentes avulsionados por paciente ............................... 55

Época do ano de maior incidência ........................................... 55 
Resultado do reimplante em função do tempo extra-alveolar ............... 56

Resultado do reimplante em função do meio de conservação ................. 56

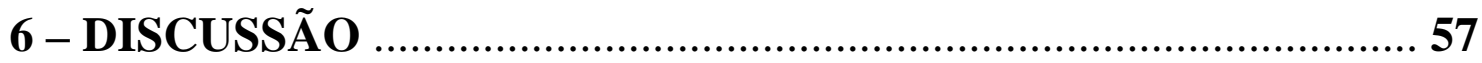

6.1 - Discussão da metodologia .......................................... 58

6.1.1 - Seleção da amostra ............................................. 58

6.1.2 - Avaliação clínica e radiográfica ......................................... 59

6.2 - Discussão dos resultados ................................................61 61

6.2.1 - Tempo de permanência extra-alveolar .............................. 61

6.2.2 - Meio usado na conservação do dente ................................. 64

6.2.3 - Preparo do alvéolo ...................................................... 65

6.2.4 - Tratamento da superfície radicular .................................67 67

6.2.5 - Tipo de contenção empregado .............................................70

6.2.6 - Medicação sistêmica ................................................... 71

6.2.7 - Proservação instituída ............................................. 72

6.2.8 - Dados epidemiológicos .................................................... 76

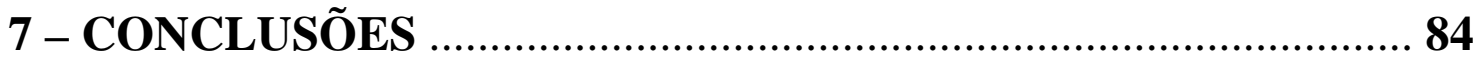

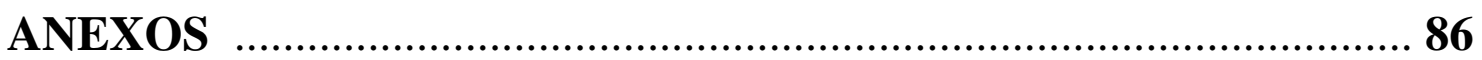

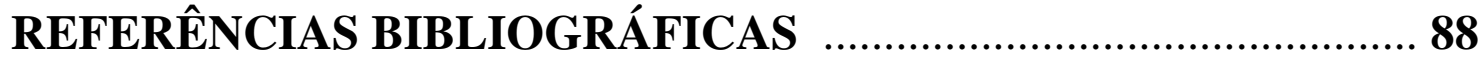

ABSTRACT 


\section{LISTA DE FIGURAS}

Figura 1 Representação gráfica dos tipos de contenção empregados....50

Figura 2 Representação gráfica dos dentes avulsionados.......................51

Figura 3 Representação gráfica da incidência por sexo.........................52

Figura 4 Representação gráfica da incidência por raça..........................53

Figura 5 Representação gráfica do número de dentes avulsionados por

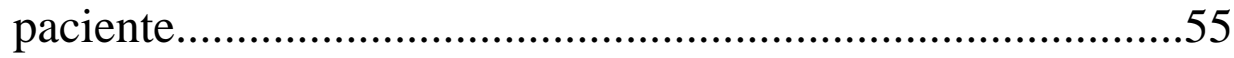

Figura 6 Representação gráfica da época do ano de maior incidência..55

Figura 7 Dente 21 em infra-oclusão....................................................59

Figura 8 Imagens radiográficas que caracterizam o resultado da reimplantação.................................................61

Figura 9 Dente 21 reimplantado após 96 horas.....................................64

Figura 10 Terapêutica endodôntica com $\mathrm{Ca}(\mathrm{OH})_{2}$ por longo período....76

Figura 12 Intervenção endodôntica tardia (3 anos após o reimplante) 83 


\section{LISTA DE TABELAS}

Tabela 1 Pacientes acidentados com avulsão traumática de dentes

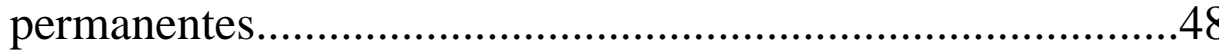

Tabela 2 Tempo de permanência extra-alveolar...................................48

Tabela 3 Meios usados na conservação dos dentes................................49

Tabela 4 Medicação sistêmica prescrita..................................................50

Tabela 5 Procedimentos endodônticos realizados.................................51

Tabela 6 Idade dos pacientes na avulsão................................................52

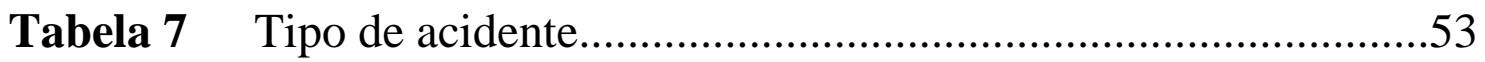

Tabela 8 Ambiente de ocorrência........................................................53

Tabela 9 Distribuição dos acidentes no período analisado.....................54

Tabela 10 Resultado do reimplante em função do tempo extra-alveolar.56

Tabela 11 Resultado do reimplante em função dos meios de conservação que foram mais utilizados..................................56

Tabela 12 Autores e incidência por sexo.............................................78

Tabela 13 Autores, número e percentual de dentes avulsionados por paciente 


\section{RESUMO}

O objetivo deste trabalho, foi analisar os prontuários de pacientes acidentados, que tiveram dentes avulsionados e reimplantados no período de 1983 a 2000, atendidos no Serviço de Urgência Odontológica da Faculdade de Odontologia de Bauru da Universidade de São Paulo. Foram coletados dados sobre: o tempo de permanência extra-alveolar, o meio usado na conservação do dente avulsionado e o tipo de contenção empregado, assim como a proservação instituída, correlacionando-os com a situação atual do dente reimplantado. Esta análise foi complementada pelos seguintes dados epidemiológicos: elementos dentais mais atingidos, idade do paciente na época da reimplantação, sexo, raça, tipo de acidente, ambiente de ocorrência, época do ano de maior incidência e o número de dentes avulsionados por paciente. Desse modo os dados obtidos foram os seguintes:

- Foram atendidos 87 pacientes, totalizando 116 dentes avulsionados.

- O tempo de permanência extra-alveolar variou de 30 minutos (13,8 \%) até 96 horas (1,1\%).

- O meio mais utilizado para conservação do elemento dental avulsionado foi o leite $(43,5 \%)$.

- O tipo de contenção mais empregado foi a esplintagem com resina composta (50,0 \%).

- Os dentes mais atingidos foram os incisivos centrais superiores (72,4 $\%)$.

- A avulsão ocorreu com mais freqüência na faixa etária compreendida entre 8 e 12 anos.

- Predominância do sexo masculino (60,9 \%) em relação ao sexo feminino $(39,1 \%)$. 
- $81,6 \%$ dos pacientes são da raça branca, 17,2 \% negros e 1,2 \% amarelos.

- Os acidentes ocorreram com maior freqüência no outono.

- 21,9 \% dos acidentados tiveram mais que 1 dente avulsionado.

Confrontando essas informações com a literatura pertinente pode-se observar que os nossos dados são semelhantes àqueles contidos nos estudos sobre avulsão e reimplantação e concluir que nos últimos 5 anos o grau de conhecimento do público leigo em relação à conservação de dentes avulsionados evoluiu muito, porém, ainda predomina entre os profissionais da Odontologia o conceito do reimplante imediato, independente do tempo de permanência extra-alveolar e do meio de conservação utilizado.

A terapêutica endodôntica realizada com curativo intracanal de hidróxido de cálcio, pelo período de 1 a 2 anos, mostrou-se eficiente na prevenção da reabsorção externa inflamatória. 
Tutroduçãa 1

1 - INTRODUÇÃO 


\section{1 - INTRODUÇÃO}

A avulsão dentaria representa uma das poucas situações onde o Cirurgião-Dentista é chamado inesperadamente para diagnóstico e tratamento, numa situação que geralmente foge de sua rotina e experiência. Os casos de avulsão dental caracterizam uma injúria rara ${ }^{30}$, afetando múltiplos tecidos como: ligamento periodontal, osso alveolar, cemento, gengiva e polpa dental.

Esforço têm sido feito para desenvolver protocolos de tratamento que tenham base nos mecanismos biológicos responsáveis pelo reparo $3,4,42,92,93,105,127,148,158,160$ porém , a eficácia dos protocolos correntes não pode ainda ser bem demonstrada em humanos ${ }^{30}$ devido à complexidade de fatores que podem interferir no processo de reparo, destacando-se o tempo de permanência extra-alveolar ${ }^{8,9,78,154}$ e o meio utilizado para conservação do dente avulsionado ${ }^{22,36,37,39,81,121,132,154}$. Esses fatores influenciam diretamente no processo de reparo do ligamento periodontal, bem como a idade do paciente, e o estágio de desenvolvimento radicular $2^{25,26,60,85,90,94,153}$, que são também determinantes para a revitalização do tecido conjuntivo pulpar.

O nível de conhecimento sobre o manuseio de dentes avulsionados durante trauma acidental, tanto do público leigo como dos profissionais de Odontologia afeta substancialmente o prognóstico ${ }^{73,137}$. Por parte dos profissionais, as manobras do tratamento inicial: conservação do elemento dental avulsionado $22,36,37,39,81,121,132,154$, preparo do alvéolo dental ${ }^{18,19,42,109,130,144}$, tratamento da superfície radicular $^{42,54,103,141,144,148,162,163}$, contenção adequada ${ }^{56,59,125,126,147}$ e medicação 
sistêmica (profilática e preventiva anti-bacteriana) ${ }^{42,53,75,77,140,144,148}$, bem como a proservação que envolve periodicidade ${ }^{58,152,157}$, conscientização e motivação profissional ${ }^{34}$.

Os trabalhos de retrospectiva clínica são unânimes em apontar a reabsorção radicular externa como sendo a principal seqüela, levando, em muitos casos, à perda do dente reimplantado ${ }^{13,24,31,48,60,66,71,74,84,97,102,103,143}$, razão pela qual, o reimplante dental deve ser considerado um tratamento temporário ${ }^{103}$ apesar de alguns relatos clínicos mostrarem situações onde o dente permaneceu funcional na cavidade bucal por períodos de até 42 anos $^{1,32,64,111}$. Com a finalidade de controlar ou até mesmo evitar o processo reabsortivo, várias propostas de terapêutica são encontradas na literatura ${ }^{58,68,76,95,96,98,105,136,157,158,159}$.

O processo de reabsorção dentária envolve uma elaborada interação entre células inflamatórias, clásticas e tecidos mineralizados. Freqüentemente esta condição dificulta o diagnóstico, prognóstico e tratamento. Injúrias e irritação no osso, dentina e cemento levam a alterações bioquímicas nesses tecidos resultando na formação de células gigantes multinucleadas referidas anteriormente como clastos ${ }^{117}$.

\section{ANDREASEN \& HJORTING-HANSEN ${ }^{13}$ em 1966,} baseados em exames radiográficos e material histológico de humanos, propuseram inicialmente 3 modelos de reabsorção: reabsorção superficial, reabsorção por substituição e reabsorção inflamatória. A reabsorção radicular também pode ser classificada como "não invasiva” (reabsorção superficial) ou “invasiva” (por substituição ou inflamatória). O perfeito entendimento destes mecanismos se faz necessário para uma correta 
avaliação do sucesso ou fracasso dos reimplantes e compreensão do processo de reparo.

REABSORÇÃO SUPERFICIAL: é um processo próprio do organismo, associado com a renovação fisiológica do cemento freqüentemente encontrada em dentes reimplantados ${ }^{30}$ ou, submetidos à mecânica ortodôntica e tratamento periodontal ${ }^{155}$. Histologicamente observa-se pequenas e superficiais cavidades no cemento e dentina, sem reação inflamatória no ligamento periodontal. Nos dentes reimplantados ela é resultante de dois processos: energia e direção do impacto durante a avulsão $^{30,74,123}$ e durante a manipulação do dente para o reimplante. Este fenômeno não é um processo patológico, representa reparo de danos ou alterações fisiológicas em tecidos mineralizados pelo recrutamento de células do tecido normal adjacente ${ }^{40,77}$. Uma nomenclatura alternativa para a reabsorção superficial foi proposta por HAMMARSTRÖN \& LINDSKOG $^{77}$ que sugeriram os termos "reabsorção radicular associada com necrose secundária” ou “necrose associada com reabsorção radicular”, baseados em observações histológicas.

\section{REABSORÇÃO POR SUBSTITUIÇÃO}

(ANQUILOSE DENTOALVEOLAR): quando extensas áreas do ligamento periodontal são perdidas ou lesadas durante a avulsão ou removidas mecanicamente antes do reimplante, uma fusão entre dente e osso alveolar pode ocorrer, ${ }^{6,77,155}$. Após injúrias severas, como luxações intrusivas e avulsões, e também depois de prolongado período extraalveolar, a membrana periodontal encontra-se ausente ou necrótica em amplas áreas da raiz. Um processo inflamatório remove os restos necróticos da superfície radicular e, posteriormente o reparo será seguido por uma competição entre células vitais do ligamento periodontal remanescentes nas paredes do alvéolo e a invasão de osso através do espaço periodontal. Este 
fenômeno também pode ocorrer após a reabsorção radicular inflamatória ter sido revertida. Se a área afetada pela reabsorção inflamatória for grande, fica extremamente difícil para as células do ligamento periodontal povoarem toda a região antes das células produtoras de osso invadirem o espaço correspondente ao ligamento.

\section{REABSORÇÃO EXTERNA INFLAMATÓRIA: a}

extrusão ou intrusão do dente, bem como o subseqüente reposicionamento ou procedimentos de reimplante provocam inevitáveis danos à raiz, resultando em áreas desnudas da superfície radicular e reação inflamatória, dando início a uma reabsorção superficial que acaba expondo a dentina. Devido ao deslocamento do dente, ocorre o rompimento dos vasos sanguíneos no forame apical provocando uma necrose pulpar pós isquêmica. A combinação de microorganismos e seus produtos com substâncias provenientes da necrose pulpar $^{117}$, estimula a inflamação no tecido periodontal dando início a uma agressiva e progressiva reabsorção da raiz ${ }^{117}$. Entretanto, se os fatores irritantes forem removidos a reabsorção externa inflamatória pode ser controlada, o mesmo não ocorre com a reabsorção por substituição ${ }^{34}$.

A partir destas considerações fundamentadas na literatura pertinente, o profissional deverá ter conhecimento das fases do tratamento inicial:

\section{- CONSERVAÇÃO DO ELEMENTO DENTAL AVULSIONADO:}

definir corretamente qual o meio mais indicado para tal, principalmente nos casos de permanência extra-bucal prolongada (acima de 30 minutos), ou mantido em meio inadequado, como por exemplo água, saliva, álcool e etc.. Visando uma possível revitalização das células do ligamento periodontal, podem ser utilizadas soluções como a de 
HANK'S (muito utilizada em cultura de tecidos) e também o VIASPAN (normalmente utilizado para o transporte de órgãos a serem transplantados) $)^{81,134,157}$.

- PREPARO DO ALVÉOLO: manobra executada com cautela, que consiste na remoção cuidadosa do coágulo sangüíneo, evitando a remoção das fibras do ligamento periodontal remanescentes aderidas às paredes do osso alveolar.

- TRATAMENTO DA SUPERFÍCIE RADICULAR: procedimento que deve ser definido em função do tempo de permanência extra-alveolar e meio utilizado no armazenamento para transporte do dente avulsionado. Em função dessas variáveis, pode ser necessária a remoção do ligamento periodontal que se encontra aderido à raiz. Esse procedimento pode ser realizado de duas maneiras: raspagem delicada e limitada apenas às fibras periodontais ou, imersão em solução de hipoclorito de sódio a 5\% preconizada por GORDON; DAMATO; CHRISTNER ${ }^{67}$. Há, ainda, na literatura, sugestões para aumentar a dureza do cemento como submergir o dente avulsionado e desprovido do ligamento em soluções contendo flúor (SHULMAN; KALIS; GOLDHABER, $1968)^{150}$.

- CONTENÇÃo ADEQUADA: esta deverá ser confeccionada de maneira que permita uma movimentação funcional do dente (semirígida) no seu alvéolo, por um período adequado, que de modo geral compreende 7 dias.Todavia, este período pode se estender para 10 ou 15 dias quando o reimplante for feito num período superior a 2 horas. A estimulação mastigatória incentiva uma rápida repopulação das áreas necróticas do ligamento periodontal, por vasos, fibroblastos e células mesenquimais, reorganizando as fibras periodontais (ANDERSON et.al., 1985) ${ }^{7}$. 
- MEDICAÇÃO SISTÊMICA: prescrição de medicação profilática e preventiva anti-bacteriana e principalmente anti-tetânica. O desenvolvimento de um processo infeccioso vai bloquear todo o processo de reparo e a instalação do tétano poderá comprometer a vida do paciente, considerando que o bacilo tetânico é anaeróbio facultativo, desenvolvendo-se muito bem numa ferida profunda como o alvéolo dental.

- PROSERVAÇÃO: instituir a terapêutica endodôntica adequada e controles periódicos de maneira padronizada, que devem ser realizados por longos períodos. Neste aspecto, o paciente deverá ser bem orientado e motivado evitando desta maneira sua frustração em relação ao tratamento.

Pelas considerações até aqui apresentadas e fundamentadas na literatura, observa-se a importância do tratamento inicial adequado e a proservação criteriosa dos casos de avulsão dental. Sendo assim, um levantamento clínico e epidemiológico de 18 anos, para uma avaliação dos procedimentos que foram realizados, vai permitir uma comparação com a literatura pertinente e sugerir ou manter condutas nos casos de reimplantação de dentes avulsionados acidentalmente. 


\section{2 - REVISÃO DE LITERATURA}

No século XIX, a transplantação dental era uma operação realizada para benefício dos nobres e opulentos do Velho Mundo (YOUNGER, $1886^{166}$ ). Entre os pobres, procuravam-se portadores de dentes íntegros, com características morfológicas e dimensionais similares aos dentes condenados dos mais afortunados. Os “doadores” vendiam seus dentes e submetiam-se à cirurgia juntamente com os beneficiários que, imediatamente após terem seus dentes condenados extraídos, recebiam os transplantes cobertos por coágulo sangüíneo, placa, cálculo, etc. Juntamente com os dentes, recebiam também inoculações de agentes infecciosos, às vezes, com conseqüências fatais . Este procedimento era veementemente combatido por estudiosos da época, que resolveram pesquisar sobre essa operação.

Com o intuito de verificar se era possível o restabelecimento do ligamento periodontal nos dentes transplantados, YOUNGER $^{166}$, em 1886, relatou ter repetido a experiência de HUNTER $^{82}$ : implantou dente humano em crista de galo e, após alguns dias, analisou o implante histologicamente, observando "união vital" entre o dente e os tecidos circundantes. Ele acreditava que o sucesso de seus transplantes era devido à remoção do tecido pulpar e obturação do canal, limpeza do dente e armazenamento em água morna durante uma hora, para preservação da membrana periodontal, seguido de desinfeção em solução de bicloreto de mercúrio, durante 15 minutos. Posteriormente, SCHEFF $^{146}$ no ano de 1890, sugeriu, após experimentação em animais, que a reabsorção não ocorreria quando os dentes fossem reimplantados com sua membrana periodontal. 
WILKINSON $^{164}$, no ano de 1917, mostrava-se mais cético: achava que a presença ou ausência da membrana não tinha influência na reabsorção, a qual ocorreria sempre em variada extensão. Em 1944, HEISS $^{79}$ foi mais afoito ainda, afirmando que a manutenção da membrana poderia até ser danosa à regeneração do ligamento, enquanto que BODECKER \& LEFKOWITZ ${ }^{41}$, 1935, já haviam se pronunciado sobre a permanência da membrana periodontal vital como absolutamente imprescindível ao processo de reparação dos reimplantes.

Apesar da preocupação dos autores daquela época, as pesquisas sobre os fatores que podem influenciar no prognóstico do dente reimplantado só se ampliaram nas cinco últimas décadas, conforme os recursos disponíveis.

Um desses fatores, a remoção da membrana periodontal, mereceu a atenção de LINGHORNE \& O'CONNEL ${ }^{99}$ em 1950; removeram-na cirurgicamente, bem como tecido ósseo alveolar, em cães, relataram posterior reinserção gengival, deposição de novo cemento sobre o cemento ou a dentina já atingidos pela reabsorção e fibras dispostas paralelamente à superfície radicular.

A eliminação do tecido pulpar, outro dos possíveis fatores, foi primeiramente estudado em 1955 por BUTCHER \& VIDAIR ${ }^{43}$ que, entretanto, não estavam interessados na relação obturação de canais/reimplantação dental, mas sim, na obtenção de invaginação de tecido periapical para o interior do canal. Seguiram-se outros trabalhos, com reimplantação dental em hamsters, nos quais não foi verificada a influência da membrana periodontal ou do tecido pulpar; apenas a 
consistência da dieta foi objeto desses estudos. Sendo a sólida associada com menor grau de anquilose (COSTICH et al. ${ }^{50}$, 1958; FLANAGAN \& MYERS $^{63}$, 1958).

A primeira citação de reabsorção radicular encontrada na literatura, é creditada a BATES ${ }^{33}$ em 1856 com o trabalho “Absorption” que foi o precursor de inúmeros trabalhos relacionados ao tema, até que HENRY; WEINMANN ${ }^{80}$, em 1951, publicaram o excelente The Pattern of Resorption and Repair of Human Cementum, um trabalho pioneiro e inédito até os dias atuais. Após analisarem histologicamente cortes de dentes humanos extraídos juntamente com os tecidos de suporte, de pacientes encaminhados a vários hospitais para necrópsia concluiram que a reabsorção:

- É comum, mas não fisiológico para o dente, algum grau de reabsorção durante sua vida.

- A idade é um fator de contribuição para causar reabsorção.

- Ocorre com mais freqüência nas superfícies que estão voltadas para a direção do movimento fisiológico .

- Reabsorções radiculares de dentes permanentes são usualmente pequenas, rasas e prontamente reparadas.

- O tamanho da área reabsorvida é um bom índice para sua severidade, enquanto o número de áreas indica o número de incidentes que causaram a reabsorção radicular.

- O terço apical da raiz é o sítio mais comum da reabsorção, decrescendo à medida que se aproxima da coroa.

- Áreas relativamente pequenas são identificadas na radiografia, quando tomada em condições ideais. 
- Trauma parece ser o mais importante fator local no desenvolvimento da reabsorção.

Em 1959, OTSBY ${ }^{129}$ atribuiu a reabsorção pósreimplantação dental à hemorragia causada pela ruptura de vasos do ligamento periodontal, com conseqüente formação de tecido de granulação. Logo depois, no ano de 1961, LÖE; WAERHAUGH ${ }^{101}$ publicaram o resultado de reimplantes dentais em cães e macacos, trabalho esse de grande repercussão na época, onde verificaram a influência da remoção da membrana ou sua desidratação com ar, em dentes com obturação de canal (porém, a última condição não entrou como variável na análise dos resultados). Concluíram que o sucesso do reimplante parecia depender da vitalidade da membrana periodontal. A influência da obturação do canal previamente ao reimplante foi estudada em cães por KNIGHT et $\mathrm{al}^{91}$, em 1964, concluiram que: os dentes reimplantados com obturação dos canais radiculares sofreram menor reabsorção que aqueles nos quais o tecido pulpar não fora removido.

ÖHMAN ${ }^{120}$, em 1965, estudou as alterações pulpares pós-reimplante, em dentes humanos: verificou ser a necrose mais freqüente nos dentes com ápice completo que nos dentes em processo de rizogênese, mas não relacionou o estágio de desenvolvimento radicular com possíveis efeitos no ligamento periodontal.

ANDREASEN; HJORTING-HANSEN ${ }^{13}$ numa publicação de 1966, relacionaram a maior porcentagem de êxito com a menor extensão do período extra-bucal, a partir de dados clínicos e histológicos. ANDERSON; SHARAV; MASSLER ${ }^{5}$, em 1968, também estabeleceram a mesma relação, porém, associaram o estágio de 
desenvolvimento dental ao período extra-bucal, não considerando importante a condição de armazenamento.

Em 1968, GREWE; FELTS ${ }^{69}$ verificaram, em estudo autoradiográfico, que reimplantes e transplantes de incisivos inferiores de camundongos, em fase precoce de desenvolvimento radicular, não interferiram no desenvolvimento e maturação, em 75\% dos casos. KAQUELER; MASSLER ${ }^{86}$, no ano seguinte, concluíram que nos estudos de reimplantes dentais, a reabsorção cervical era decorrente do procedimento de extração; também deram ênfase ao maior êxito dos reimplantes de dentes durante a rizogênese. Quanto à conveniência ou não do tratamento endodôntico ser realizado previamente ao reimplante, ainda nesse mesmo ano, ROTHSCHILD et al. ${ }^{138}$, após experimentação em cães, relataram que dentes com canais obturados foram associados à maior porcentagem de êxito.

No ano de 1970, GROPER; BERNICK ${ }^{70}$ forneceram outra informação aparentemente contraditória com as existentes: dentes de cães por eles reimplantados imediatamente ou após 10, 15, 30 minutos ou ainda 1, 3, 8 ou 24 horas, apresentaram ligamento periodontal funcional. Nenhum efeito foi atribuído à secagem da membrana periodontal. Outra informação de interesse para os estudos sobre reimplantes, principalmente considerando-se as afirmações sobre a necessidade da vitalidade da membrana periodontal, foi fornecida em 1971 por LITWIN et al. ${ }^{100}$ que, após estocar dentes em meio de cultura, verificaram que as células da superfície radicular podiam manter-se vitais por até onze meses.

CVEK et al. $^{52}$, em 1974, seguindo uma série de trabalhos sobre obturação de canal com hidróxido de cálcio em dentes 
humanos, deram novamente ênfase ao período extra-bucal, no caso dos reimplantes. Verificaram ser maior a ocorrência de anquilose quando esse período era maior que 15 minutos, permanecendo o dente seco; porém, ela diminuía quando ao período de secagem, seguia-se outro, de hidratação.

O período extra-bucal dos reimplantes foi também relacionado com a manutenção da vitalidade pulpar. MASSLER ${ }^{107}$, em 1974, considerou que: dentes durante a rizogênese tem boas chances de manutenção quando tal período, é de até 30 minutos; poucas de 30 minutos a 6 horas, e inexistente após 6 horas. Esse autor chamou a atenção também para a fixação do dente reimplantado: quando ela permitia certa mobilidade dental, observava-se arranjo funcional das fibras periodontais, enquanto a fixação rígida associava-se com fibras dispostas em paralelo com o longo eixo dental.

Entretanto, ANDREASEN ${ }^{15}$ relatou em 1975 a ocorrência de anquilose em dentes de macacos reimplantados após 120 minutos de permanência extra-alveolar, independente do método de contenção; a incidência de anquilose, em dentes com período extra-alveolar de apenas dezoito minutos, era menor nos dentes não submetidos à fixação . Em dentes humanos, ele considerou a fixação durante uma semana como benéfica para o dente reimplantado ${ }^{16}$, com sinais indicadores de rápido reparo periondontal. Ainda neste ano, NASJLETI et al. ${ }^{115}$, após estudo em macacos, observaram que o tecido epitelial inicia sua proliferação imediatamente após o reimplante e, aos sete dias pós-operatórios, o epitélio juncional já se encontra restabelecido.

Outros dados sobre a relação tratamento endodôntico/sucesso do reimplante foram apresentados também em 1975 
por OKAMOTO et al. ${ }^{128}$; que obturaram a cavidade pulpar de incisivos extraídos de ratos, antes de reimplantá-los, o que não impediu o desencadeamento de extensas reabsorções-dentinárias. Acreditaram ser esse resultado conseqüente do fato de que, ao serem removidas a polpa e a papila dental, foram removidas também porções de cemento e dentina pouco mineralizadas, provocando o contato do material obturador com o ligamento periodontal. Salientaram, também, a ação irritante desse material ao ligamento, através dos canalículos dentinários, já que os efeitos mais danosos foram observados na superfície lingual, que não conta com a proteção adamantina que existe na vestibular.

Ainda em 1975, em decorrência de pesquisas com interesse voltado para problemas periodontais, ALEO et al. ${ }^{2}$ obtiveram um resultado muitíssimo interessante, que poderia mudar a orientação nos estudos sobre reimplantes: a remoção mecânica do cemento dental propiciou uma superfície biologicamente compatível para união de fibroblastos gengivais, in vitro.

Voltando à influência da contenção, GAYNOR ${ }^{65}$ em 1976, trabalhando com dentes humanos reimplantados, considerou vantajosa aquela feita através da desmineralização ácida e aplicação da resina composta.

Mais informações sobre a influência do tratamento endodôntico nos reimplantes dentais em cães foram apresentados por WOEHRLE ${ }^{165}$ também em 1976: grande neoformação cementária foi associada com o tratamento, enquanto que nos dentes apenas despolpados ou com polpa mantida intacta, a neoformação foi bem menor. Outro detalhe muito importante fornecido por esse autor foi a observação de que a 
deposição cementária ocorreu também em sulcos preparados na raiz, sulcos esses que expunham a dentina; aliás, isso talvez pudesse ser esperado, já que as células do ligamento periodontal são responsáveis tanto pela formação de osso, como de fibras e cemento ${ }^{110}$.

SÖDER et al. ${ }^{154}$ em 1977, estudaram in vitro a influência do período extra-alveolar em meio seco, sobre a vitalidade das células da membrana periodontal, usando dentes de macacos e humanos. Após extração os dentes foram mantidos secos por 0, 30, 60, 90 e 120 minutos, sendo a viabilidade celular examinada através de cultura para tecidos. Concluiram que a viabilidade celular declina rapidamente com o aumento do período extra-alveolar em meio seco e que, após 2 horas nessa condição não foi possível demonstrar viabilidade celular.

As pesquisas sobre reimplantação dental se intensificaram até a década de 70, porém foi a partir da década de 80 que os conhecimentos sobre o assunto tiveram um avanço considerável.

O armazenamento de dentes antes da reimplantação mereceu a atenção de ANDREASEN et al. ${ }^{17}$ em 1978; eles verificaram que a imersão em meio de cultura tecidual por 5 a 14 dias, levava a um reparo periodontal superior, com menor reabsorção inflamatória, mesmo que os dentes fossem desidratados durante uma hora, se contrapondo aos achados de SÖDER et al. ${ }^{154}$. Também preocupados com a manutenção da vitalidade da membrana periodontal BLOMLÖF et al. ${ }^{36,37}$, em 1980, pesquisaram sobre condições de estocagem que melhor influenciassem o resultado dos reimplantes dentais; comparando a imersão em solução salina, saliva e leite, concluíram ser esta última opção a melhor. Nesse mesmo ano, COMFORT $^{49}$, observou que o armazenamento de dentes em meio de 
cultura tecidual possibilitou a manutenção de sua vitalidade por mais de 11 meses, período esse muito mais longo que o apontado por ANDREASEN et al. ${ }^{17}$.

Ainda em 1980, um grupo de pesquisadores verificou, em macacos, a influência de diversas variáveis no êxito dos reimplantes (OSWALD et al. ${ }^{130,131}$; VAN HASSEL et al. ${ }^{162}$ ), tais como: remoção do osso alveolar, remoção da membrana periodontal , período extra-alveolar, armazenamento em saliva e obturação de canal anterior ao reimplante ou mediata; consideraram a remoção do osso alveolar como tendo alguma influência benéfica ${ }^{130}$, a manutenção da membrana vital como essencial ${ }^{162}$ e o armazenamento em saliva como fator significante na retenção do dente sem reabsorção observável radiograficamente ${ }^{131}$. Os autores em consideração fizeram uma observação interessante quando da conclusão de que a manutenção da membrana íntegra era de vital importância ${ }^{162}$, referindo-se a um caso em que a membrana fora removida e o dente seco com ar durante uma hora, não apresentando reabsorção 25 meses depois, disseram: "talvez ocorra com os dentes o mesmo que com algumas pessoas; há aquelas intransigentes que conseguem sobreviver nas mais adversas circunstâncias”. ANDREASEN ${ }^{18}$, também em 1980, avaliou em macacos o efeito da remoção do coágulo previamente ao reimplante, concluindo que este procedimento não influi no reparo do ligamento periodontal e tão pouco do tecido pulpar, sugerindo ainda que: o reimplante de dentes avulsionados deve ser realizado imediatamente sem necessidade de remover o coágulo.

Logo depois, em 1981, ANDREASEN \& KRISTERSON $^{20}$ relataram seus resultados de reimplantes em macacos, após testarem a oportunidade da realização do tratamento endodôntico, 
utilizando o hidróxido de cálcio como material obturador; concluíram que a obturação deve seguir-se à reimplantação, com um intervalo de tempo que possibilite o início da reparação do ligamento periodontal.

SKOGLUND \& TRONSTAD ${ }^{153}$, em 1981, voltaram a se preocupar com a possibilidade de revascularização pulpar em dentes com raízes completas, apicectomizados, ou em dentes em processo de rizogênese, respectivamente. A revascularização observada reduzia-se após períodos de observação mais longos. Um estudo de MORRIS et al. ${ }^{114}$, também em 1981, apresenta um resultado surpreendente: afirmaram os autores que o fator mais relacionado com a reabsorção de dentes transplantados era o período em que o alvéolo permanecia vazio, e não o período extra-bucal do elemento dental.

Quanto à influência do procedimento de limpeza do elemento dental antes do reimplante, WEINSTEIN et al. ${ }^{163}$, em 1981, relataram ser menor a reabsorção de dentes submetidos à água corrente do que nos mergulhados em saliva. ANDREASEN \& KRISTERSON ${ }^{21}$, após pesquisarem o efeito da secagem ou remoção parcial do ligamento periodontal em reimplantes de incisivos de macacos, assim se pronunciaram: “A formação de um novo ligamento periodontal, após sua remoção, sem sinais de reabsorção, indica que a remoção física das fibras do ligamento e de cementoblastos não leva automaticamente à reabsorção radicular".

MATSSON et al. ${ }^{108}$, em 1982, verificaram que mesmo que o dente avulsionado fosse mantido seco por curto período de tempo, sua reidratação prévia ao reimplante diminuía os riscos de anquilose. Nesse mesmo ano NASJLETI et al. ${ }^{116}$, associaram período curto de imobilização 
(7 dias) com reparação, e período longo (30 dias) com reabsorção e anquilose, em dentes reimplantados em macacos.

Em 1983, BLOMLÖF et al. $^{38}$ apontaram como importante fator para o êxito do reimplante o impedimento da secagem da membrana periodontal, após envolvê-la em plástico durante o período extra-bucal. Esse mesmo autor e equipe, no mesmo ano, verificaram que a reimplantação dental após armazenamento em leite propiciava melhores resultados que o feito em saliva ${ }^{39,132}$.

HEIMDAHL et al. $^{78}$, em 1983, baseados em observações clínicas, forneceram novos dados sobre reimplantes dentais em humanos, realizados após longo período extra-bucal (variando de 6 horas a 48 dias) armazenados em meio de cultura ou mantidos secos; não observaram relação entre extensão da reabsorção com o período extra-bucal e concluíram que o tratamento endodôntico podia prevenir a reabsorção inflamatória, mesmo após período extra-bucal longo.

Os conhecimentos sobre a influência do estágio de desenvolvimento radicular, foram em 1984, enriquecidos por KRISTERSON \& ANDREASEN ${ }^{94}$ que realizaram o seguinte experimento em macacos: 50 dentes em 3 diferentes estágios da rizogênese foram reimplantados após 18 minutos de permanência extra-alveolar, sendo divididos em 2 grupos experimentais. O primeiro grupo recebeu tratamento endodôntico prévio (obturação com guta percha e cimento), no segundo nenhum procedimento prévio ao reimplante foi realizado, sendo os animais sacrificados depois de 8 semanas e os dentes reimplantados submetidos a análise histológica. Os autores observaram que a extensão da vitalidade pulpar era significativamente proporcional ao estágio do desenvolvimento 
radicular, praticamente completa nos dentes com rizogênese incompleta e parcial naqueles que apresentavam a raiz já desenvolvida.

Reabsorção superficial foi observada com a mesma freqüência nos diferentes estágios de desenvolvimento radicular, enquanto a reabsorção inflamatória era ligeiramente mais freqüente em dentes maduros jovens do que em dentes maduros, um achado possivelmente relacionado a uma ação protetora da camada de cemento, que é mais espessa nestes elementos. O processo de reabsorção por substituição aparecia com a mesma freqüência nos dentes sem tratamento endodôntico prévio, independente do estágio de formação radicular. As conclusões desta pesquisa foram confirmadas em casos clínicos publicados por JOHNSON et al. ${ }^{85}$ e MENEZES et al. ${ }^{114}$, ambos em 1985.

Preocupados com os efeitos da estimulação mastigatória no desenvolvimento da anquilose em dentes reimplantados, ANDERSSON et al. $^{7}$, em 1985, realizaram um experimento em macacos. Os animais tiveram seus incisivos superiores extraídos, secos ao ar durante 1 hora, tratados endodonticamente e reimplantados sem utilizar nenhum tipo de contenção. Divididos em 2 grupos, receberam dietas diferentes: um grupo recebeu alimentação em grãos (duros), enquanto ao outro era fornecida uma dieta macia, por um período de 8 semanas. Os dentes reimplantados nos animais que receberam dieta dura apresentaram menos anquilose e, uma área maior da superfície radicular com membrana periodontal normal, quando comparados ao grupo que recebera a dieta macia. Concluiram os autores que, o desenvolvimento da anquilose pode ser parcialmente prevenida ou reduzida pela estimulação mastigatória, opinião esta que foi confirmada em 1986 por HAMMARSTRÖM et al. ${ }^{74}$. 
ANDREASEN \& SCHWARTZ ${ }^{22}$, em 1986, extrairam 20 incisivos centrais superiores de 10 macacos, que permaneceram fora da boca e expostos ao meio ambiente por 30 minutos, sem nenhuma intervenção endodôntica. Um grupo (10 dentes) após esse período foi reimplantado. Os 10 dentes do outro grupo, após o mesmo tempo, foram colocados em solução salina por mais 30 minutos e em seguida reimplantados. Não foi feito nenhum tipo de contenção após o reimplante. Oito semanas após, os animais foram sacrificados e a análise histomorfométrica mostrou idêntica extensão de anquilose em ambos os grupos. A conclusão deste trabalho foi que a solução salina não teve nenhuma propriedade para controlar ou impedir a reabsorção radicular, ficando assim demonstrado que os meios de conservação que não possuam propriedades revitalizadoras (somente mantenedoras da vitalidade celular), apenas são eficientes se o dente avulsionado for neles colocado imediatamente após a avulsão. Na realidade, os 30 minutos em que os dentes ficaram expostos ao meio ambiente, foram responsáveis por lesões graves no ligamento periodontal que a solução salina não teve propriedades para restabelecer.

Para HAMMARSTRÖM et al. ${ }^{75,77}$, em 1986 e 1989, respectivamente, a administração de antibióticos por via sistêmica, eliminou a ocorrência de reabsorção do tipo inflamatória e diminuiu entre 30 e 45\% a superfície da área radicular com ocorrência de anquilose. Neste mesmo ano KLING; CVEK; MEJÀRE ${ }^{90}$, estudando dentes reimplantados em humanos, mais especificamente a relação entre os fatores: diâmetro do forame apical, tempo extra-alveolar, meio utilizado na conservação do dente e administração de antibióticos, não observaram resultados significantes nos pacientes que receberam esta medicação. Concluíram ainda que, incisivos da maxila têm maiores possibilidades de 
revascularização que os da mandíbula. Um fator importante para que possa haver a revascularização é a posição do dente quando do reimplante, ele deve alojar-se perfeitamente em sua posição original, de modo que não haja distância entre o forame apical e a parede apical do alvéolo. Este contato íntimo facilitará sem dúvida, a infiltração de novos vasos no interior da polpa.

Mais tarde, no ano de 1990, CVEK et al. ${ }^{53,54}$ voltaram a estudar os benefícios da antibioticoterapia sistêmica e tópica, fazendo reimplantação de dentes em macacos, observando que a aplicação tópica de dicloxacilina antes do reimplante, diminuía os níveis de reabsorção externa inflamatória.

HAMMARSTRÖM et al. $^{76}$, em 1986, investigaram o efeito do hidróxido de cálcio sobre as células presentes na superfície radicular e no ligamento periodontal, por meio de microscopia óptica e eletrônica de varredura. Neste experimento, extraíram incisivos laterais de macacos fazendo uma canaleta na raiz e imediato reimplante; as polpas de alguns dentes foram infectadas propositalmente por bactérias presentes na saliva. A aplicação de hidróxido de cálcio no canal radicular causou uma necrose parcial das células que reabsorvem dentina como também naquelas responsáveis pela formação de cemento reparador. Nos dentes não infectados, observaram o desenvolvimento de anquilose temporária. $\mathrm{O} \mathrm{pH}$ elevado, que tem efeito necrotizante e bactericida, parece ser suficiente para explicar o efeito terapêutico do hidróxido de cálcio na reabsorção radicular.

Em 1987, MATSSON; KLINGE; HALLSTRÕM ${ }^{109}$ realizaram o seguinte experimento: 18 incisivos de cães da raça beagle 
foram extraídos, armazenados secos durante 30 minutos para induzir um dano padronizado nas células do ligamento periodontal, reimplantados e esplintados. Irrigação contínua com solução salina até a obtenção da hemostasia foi executada em 9 alvéolos, no outro grupo foi permitida a formação do coágulo sangüíneo. Após 2 semanas os canais radiculares foram limpos e preenchidos com hidróxido de cálcio, sendo removida nesta ocasião a esplintagem. Após 3 meses os animais foram sacrificados e as pré-maxilas processadas por métodos histológicos rotineiros. A anquilose dentoalveolar foi encontrada em 3 dentes reimplantados nos alvéolos irrigados com a solução salina, enquanto 8 dentes reimplantados nos alvéolos que não receberam a irrigação, estavam anquilosados.

Trabalhos foram realizados para testar a eficácia da medicação intracanal com o objetivo de eliminar a reabsorção externa inflamatória. O trabalho de PIERCE; HEITHERSAY; LINDSKOG ${ }^{136}$, em 1988, adotou a estratégia de examinar o efeito de uma associação corticoesteróide e antibiótico (Ledermix ${ }^{\circledR}$ Paste, Lederle Pharmaceuticals, Wolfratshausen, FRG), diretamente sobre dentinoclastos cultivados in vitro. Os resultados mostraram que o componente esteróide da pasta, inibiu diretamente a capacidade de "espalhamento" dos dentinoclastos, sugerindo que este medicamento atua separando estas células da superfície radicular. Ainda neste ano, estes pesquisadores, tentaram a aplicação intracanal de calcitonina (32 amino-acid polypeptide, hormônio secretado por células parafoliculares “C” da glândula tireóide). Os resultados foram promissores, mas não conclusivos.

ANDERSSON; BODIN ${ }^{9}$, em 1990, numa avaliação por um período de 5 anos concluíram que tanto o reimplante imediato, quanto aqueles com período extra-alveolar de até no máximo 10 minutos, 
mostraram ausência de reabsorção e que 15 minutos de tempo extraalveolar (seco) já foram suficientes para que houvesse o aparecimento de reabsorção em algumas áreas da raiz, mais uma vez demonstrando a importância do fator tempo. Alguns anos depois, 1995, ANDREASEN ${ }^{27}$ observando o percentual de destruição do ligamento periodontal quando o dente fica exposto ao meio ambiente (seco), verificou que até os primeiros 60 minutos $60 \%$ do ligamento já estava necrótico. Outro fato importante observado neste trabalho é que nos primeiros 30 minutos 20\% do ligamento periodontal é destruído e bastam mais 30 minutos para este percentual triplicar.

O trabalho desenvolvido por HILTZ; TROPE ${ }^{81}$, em 1991, comparou o Viaspan e a solução de Hank’s com o leite, utilizando células fibroblásticas humanas in vitro, fazendo uma avaliação das células vitais remanescentes num período que variou de 2 a 168 horas. O grupo armazenado no leite manteve uma alta porcentagem de células vitais por até 6 horas (68,2\%); após 12 horas a efetividade do leite caiu para 43,4\% perdendo toda a sua ação depois de 48 horas. A solução de Hank's foi extremamente efetiva por 24 horas, mantendo neste período 71,3\% das células com vitalidade, após 48 horas este percentual diminui para 38\%. O meio mais efetivo foi o Viaspan, que em período superior a 168 horas ainda apresentava 37,6\% das células com vitalidade. Como o período de até 6 horas é um tempo bastante razoável para que se faça o reimplante de dentes acidentalmente avulsionados, o leite por estar disponível mais facilmente, poderá ser empregado com segurança. TROPE et al. ${ }^{156}$, no ano seguinte, afirmaram que, quando um dente avulsionado é colocado imediatamente na solução de Hank's, o tempo passa a não ser um fator crítico para o desenvolvimento de reabsorção, demonstrando que num tempo extra- 
alveolar de até 24 horas, nesta solução, não foi detectado o aparecimento de reabsorção após o reimplante.

Por existir controvérsias na literatura quanto ao tempo de utilização do hidróxido de cálcio, como medicação intracanal em dentes avulsionados, LENGHEDEN; BLOMLÖF; LINDSKOG ${ }^{95,96}$, em 1991, realizaram um experimento em macacos, nos quais foram reimplantados dentes com a membrana periodontal necrosada. Observaram que a elevação do $\mathrm{pH}$ da superfície radicular pode exercer um efeito necrotizante nas células que reparam o periodonto e, quando uma área extensa for afetada, o tecido necrótico será reabsorvido levando a uma reabsorção por substituição. Eles concluíram que o hidróxido de cálcio é um excelente meio para o tratamento inicial, mas pode levar a uma desnecessária reabosorção por substituição, quando mantido no interior do canal por longos períodos ou substituído repetidamente. HAMMARSTRÖM et al. ${ }^{76}$ — num estudo semelhante, já visto nesta revisão - compartilham desta opinião, pois as sucessivas trocas podem provocar um efeito necrotizante em células jovens que vão repopularizar a superfície radicular, resultando desta forma em anquilose.

A maioria das técnicas de contenção dental são baseadas nos princípios de fixação de fraturas mandibulares. Desde a descoberta do ataque ácido por BUONOCORE em 1955, as resinas compostas ganharam popularidade em todas as áreas da odontologia, sendo introduzidas várias técnicas nos últimos 20 anos. Poucos trabalhos de avaliação fisiológica destas contenções foram feitos, merecendo destaque o estudo publicado em 1992 por OIKARINEN; ANDREASEN; ANDREASEN ${ }^{126}$, onde a rigidez horizontal e vertical do dente esplintado foi avaliada em 7 tipos de contenções, utilizando o Periotest ${ }^{\circledR}$ (Siemens, BRD). Foram utilizadas 21 
secções da porção anterior de mandíbulas humanas incluindo os tecidos moles e, aplicada a contenção nos incisivos com os seguintes materiais:

1 - Fermit (Vivadent, BRD), que é uma resina fotopolimerizável

2 - Fio de aço flexível associado com resina composta

3 - Kevlar (B-W Dental, Frederiksberg, DK)

4 - Malha de fibras flexíveis, revestidas com resina

5 - Protemp (Protemp II, Espe, Germany)

6 - Fio de aço rígido associado com resina composta

7 -Triad Gel (Dentsply, USA), acrílico fotopolimerizável.

Os resultados mostram que o Protemp e o fio de aço flexível associado com resina composta, produzem um adequado suporte lateral para fixação de dente e, permitem flexibilidade vertical que é desejável para o processo de reparo do ligamento periodontal ${ }^{6,62}$.

Alguns anos depois, em 1995, EBELESEDER; GLOCKNER; STÄDTLER ${ }^{59}$, voltaram ao assunto, agora avaliando a extensão lateral destas contenções. Concluíram que a imobilização envolvendo um dente vizinho ocasionou um efeito menor de fixação, quando comparada à imobilização utilizando dois dentes de cada lado, sendo aconselhável reduzir este efeito para evitar a anquilose.

SCHEIN; ISOLAN ${ }^{147}$, em 1997, considerando que tanto a rigidez quanto o tempo de utilização da contenção, são fatores diretamente proporcionais ao aparecimento da anquilose, influenciando negativamente a regeneração do ligamento periodontal e também a revascularização pulpar, acreditam que a utilização de um esplinte , obtido 
à base de resina composta somente, ou associada com fio de nylon ou fio de aço, por um curto período de tempo (NEAVERTH; GOERIG ${ }^{118}$, 1980), proporciona um melhor prognóstico quando se deseja a reorganização funcional das fibras do ligamento periodontal.

TROPE et al. ${ }^{157,159}$, em 1992 e 1995 respectivamente, estudaram histológicamente em cães, os efeitos da terapia com hidróxido de cálcio utilizada por curtos e longos períodos de tempo, no processo de reparo da superfície radicular. Foram utilizados neste estudo, 30 incisivos de cães da raça beagle, distribuídos em 4 grupos experimentais:

GRUPO 1: os dentes tiveram o canal radicular previamente obturado, logo em seguida extraídos recebendo um sulco longitudinal na raiz, sendo reimplantados em 2 minutos.

GRUPO 2: neste grupo os canais foram artificialmente infectados durante a exodontia. A preparação do sulco e o reimplante foram idênticos ao grupo 1. Decorridos 14 dias após o reimplante, os canais radiculares foram completamente instrumentados e preenchidos com hidróxido de cálcio, que permaneceu durante 1 semana. Ao final deste período, os canais foram obturados definitivamente com guta-percha e cimento.

GRUPO 3: os dentes deste grupo foram tratados exatamente como o descrito no grupo 2, com uma exceção, não foram permanentemente obturados mas sim, recebendo trocas do curativo intracanal de hidróxido de cálcio.

GRUPO 4: os canais foram infectados durante a exodontia, as raízes sulcadas e os dentes reimplantados. Neste grupo, que 
serviu como controle positivo, nenhum tratamento endodôntico foi realizado.

A análise histológica realizada após 8 semanas revelou que no grupo 1 ocorreu o completo reparo do cemento em todos os dentes; nos grupos 2 e 3, reparos completo e incompleto foram observados, inclusive, região de anquilose em um dos dentes. Em nenhum dente do grupo 4 foi notado reparo do cemento. Baseados nestes achados, os autores concluiram que a terapia endodôntica com hidróxido de cálcio por um curto ou longo período de tempo, tem resultados semelhantes quando a intervenção endodôntica é realizada até 14 dias após o reimplante.

$\mathrm{Na}$ discussão, os autores, concordam com a recomendação da American Association of Endodontists Ad Committee on Treatment of the Avulsed Tooth ${ }^{4}$, que propõe no seu protocolo de tratamento, trocas de hidróxido de cálcio a cada 3 meses durante um período mínimo de 6 meses, que pode se extender até 24 meses, para que possa exercer seu efeito neutralizador sobre as endotoxinas responsáveis pela ativação dos osteoclastos.

Em 1994, GREGORIOU; JEANSONNE; MUSSELMAN $^{68}$, praticamente repetem o experimento de TROPE et al. ${ }^{157}$. Os dentes foram examinados com microscópio óptico acoplado a um sistema computadorizado para análise de imagens, cujos dados foram submetidos à análise estatística, obtendo os mesmos resultados e conclusões. Resultado semelhante também foi obtido por DUMSHA; HOVLAND $^{58}$, em publicação de 1995. 
Analisando os trabalhos publicados até aqui, fica bastante confuso para o clínico, determinar o período de utilização do hidróxido de cálcio como medicação intra-canal. SIDLEY ${ }^{151}$, em 1990, advoga que 18 meses é o período ideal, com trocas regulares a cada 4 ou 6 meses. ANDREASEN ${ }^{23}$, numa publicação de 1992, também recomenda a utilização do hidróxido de cálcio, com a sua substituição 1 mês após o curativo inicial, seguida de trocas regulares a cada 3 ou 4 meses, pelo período que se fizer necessário.

BLOMLÖF; LINDSKOG $^{40}$, em trabalho de 1994, estudaram a formação de tecido mineralizado (cemento reparador) sobre a superfície de raízes raspadas. Neste experimento utilizaram uma metodologia diferente dos demais estudos sobre reparo do ligamento periodontal. Nos incisivos de macacos que foram cuidadosamente extraídos, removeram mecanicamente o ligamento periodontal e a camada de cemento que recobriam a face mesial da raiz, obedecendo uma distância de 1 a 2 mm da junção amelo-cementária e também do ápice radicular. Em seguida os dentes foram reimplantados. Anquilose foi observada após 3 e 5 semanas, sendo em menor grau após 5 semanas e ausente após 10 semanas. Este resultado sugere que o processo de reabsorção predomina durante 5 semanas, sendo substituído por uma fusão anquilótica. Após 10 semanas, a camada remanescente de tecido mineralizado, freqüentemente referida como cemento reparador, pode ser observada recobrindo a superfície de dentina, porém, não se apresentando firmemente aderida à superfície radicular e também com morfologia diferente do cemento normal, mas sim, várias camadas de aspecto semelhante ao osso alveolar. As fibras de tecido conjuntivo adjacentes à camada deste tecido mineralizado, não estavam funcionalmente orientadas, dispostas paralelamente à superfície radicular. 
Baseados nestes achados histológicos, concluiram os autores, que a formação de tecido mineralizado é resultante de uma anquilose transitória.

ANDREASEN; KRISTERSON ${ }^{21}$ sugeriram que, quando grandes áreas do ligamento periodontal são traumatizadas ou destruídas, ocorre uma cicatrização de forma competitiva entre células derivadas da medula óssea - programadas para formar osso - e células derivadas do ligamento periodontal que são originalmente programadas para formar fibras. O resultado dessa competição traduz-se numa anquilose, que pode permanecer como tal ou evoluir para uma reabsorção do tipo substitutiva. A anquilose somente é considerada um problema em crianças com dentes ainda em erupção, uma vez que eles ficam retidos no alvéolo. Em dentes que já atingiram a completa erupção, a anquilose não é considerada problemática.

Uma característica dos anos 90, é a grande quantidade de publicações de estudos retrospectivos e protocolos propondo seqüências de procedimentos clínicos nos casos de reimplantação dental (ALVES ${ }^{3}$, AMERICAN ASSOCIATON OF ENDODONTISTS ${ }^{4}$, BARRET; KENNY $^{30}$, BRAMANTE et al. $^{42}$, DAVIS ${ }^{55}$, KONIS ${ }^{92}$, TROPE $^{158}$ ), merecendo atenção as manobras preconizadas por KRASNER; RANKOW $^{93}$, em 1995, onde os autores descrevem 10 categorias de procedimentos:

\section{CATEGORIA 1 : rizogênese completa. Tempo extra-alveolar inferior de até 15 minutos.}

Antes do reimplante o dente deverá ser lavado por irrigação, com alguma solução fisiológica como por exemplo a solução de Hank`s, leite ou solução salina isotônica. O LPD jamais deverá ser tocado digital ou mecanicamente. 
CATEGORIA 2 : rizogênese completa. Tempo extra-alveolar entre 15 minutos e 24 horas, acondicionado em um meio que proporcione reconstituição celular (solução de Hank`s).

Nesta situação, o dente deverá ser retirado do meio reconstituinte e reimplantado imediatamente.

CATEGORIA 3 : rizogênese completa. Tempo extra-alveolar entre 15 e 360 minutos, acondicionado em meio líquido que não proporcione reconstituição celular.

Quando um dente for transportado em um meio como água de torneira, solução salina, saliva ou mesmo leite, as células do LPD certamente estarão morfológica e fisiologicamente comprometidas. Neste caso, antes do reimplante, o dente deverá ser colocado em uma solução reconstituinte (solução de Hank`s) por um tempo de 30 minutos para que as células comprometidas tenham chance de ser reparadas.

CATEGORIA 4 : rizogênese completa. Tempo extra-alveolar inferior a 120 minutos, mantido em meio ambiente (seco).

Nesta situação, as células do LPD ainda não estão necróticas, mas encontram-se seriamente comprometidas tanto fisiologica como metabolicamente. Antes do reimplante, o dente deverá ser colocado em uma solução reconstituinte (solução de Hank`s) por um tempo de 30 minutos.

CATEGORIA 5 : rizogênese completa. Tempo extra-alveolar superior a 120 minutos, mantido em meio ambiente (seco).

Após 120 minutos, praticamente todo o LPD estará necrótico, não sendo possível sua reconstiuição, mesmo que se empregue qualquer meio com esta propriedade. Nestes casos, o LPD deverá ser 
raspado cuidadosamente, com o auxílio de uma lâmina de bisturi, ou então colocado numa solução de hipoclorito de sódio por 30 minutos. Em seguida o dente deverá ser mergulhado em várias soluções na seguinte seqüência:

1. Solução saturada de ácido cítrico por três minutos, retirar e lavar com solução salina.

2. Solução de fluoreto de estanho (SnF2) a $1 \%$ por cinco minutos.

3. Solução de dicloxacilina $1 \mathrm{mg} / 20 \mathrm{ml}$ por mais cinco minutos.

Após estes procedimentos o dente deverá ser aberto, o canal preparado e obturado de maneira convencional e a cavidade de acesso restaurada. O dente deverá ser reimplantado, confeccionada uma contenção semi-rígida que deverá permanecer por um prazo que pode variar de 7 a 10 dias.

CATEGORA 6 : rizogênese incompleta. Tempo extra-alveolar inferior a 15 minutos.

Nesta situação as possibilidades para o restabelecimento total do LPD, bem como a expectativa para uma possível revascularização, é muito boa. Pela potencialidade de uma revascularização, é importante que não haja contaminação. Por este motivo, o dente antes do reimplante, deverá ser colocado em uma solução de dicloxacilina $1 \mathrm{mg} / 20 \mathrm{ml}$, por um tempo de 5 minutos. Deverá haver um acompanhamento clínico e radiográfico uma vez por semana, até que se constate o sucesso da revascularização . Por outro lado, se sinais de necrose e/ou reabsorção forem detectados, a polpa deverá ser removida imediatamente e procedimentos de apicificação deverão ser instituídos.

CATEGORIA 7 : rizogênese incompleta. Tempo extra-alveolar entre 15 minutos e 24 horas, acondicionado em um meio que proporcione reconstituição celular. 
Nestas circunstâncias as células do LPD estão em condições fisiológicas ótimas, mas a polpa pode estar infectada. Antes do reimplante o dente deverá ser mergulhado em uma solução de dicloxacilina 1mg/20 ml por um tempo de 5 minutos. O acompanhamento clínico e radiográfico deverá ser semanal e na presença de qualquer sinal de necrose e/ou reabsorção a polpa deverá ser removida e procedimentos de apicificação deverão ser instituídos.

CATEGORIA 8 : rizogênese incompleta. Tempo extra-alveolar entre 15 e 360 minutos, acondicionado em meio líquido que não proporcione reconstituição celular.

Numa situação como essa, as células do LPD não estão em condições fisiológicas ótimas, portanto necessitam ser reconstituídas. O dente avulsionado deverá ser colocado na solução de Hank`s por 30 minutos. A seguir deverá ser colocado em uma solução de dicloxacilina 1 $\mathrm{mg} / 20 \mathrm{ml}$ por 5 minutos. Após este procedimento o dente deverá ser reimplantando. O acompanhamento deverá ser semanal e se sinais de necrose e/ou reabsorção forem detectados, a polpa deverá ser removida e procedimentos de apicificação instituídos.

\section{CATEGORIA 9 : rizogênese incompleta. Tempo extra-alveolar inferior} a 120 minutos, mantido em meio ambiente (seco).

Neste caso as células do LPD estão fisiológica e funcionalmente comprometidas, mas não necróticas. O dente deverá ser colocado em solução de Hank`s por 30 minutos e a seguir por mais 5 minutos numa solução de dicloxacilina $1 \mathrm{mg} / 20 \mathrm{ml}$, e posteriormente reimplantado. O acompanhamento deverá ser semanal e se sinais clínicos e radiográficos de necrose e/ou reabsorção forem detectados a polpa deverá ser extirpada e procedimentos de apicificação instituídos. 


\section{CATEGORIA 10: rizogênese incompleta. Tempo extra-alveolar superior a 120 minutos, mantido em meio ambiente (seco).}

As células do LPD e da polpa estão necróticas e não poderão ser revitalizadas pela solução de Hank`s, Viaspan ou outra solução qualquer. O LPD deverá ser delicadamente raspado com uma lâmina de bisturi ou o dente colocado em uma solução de hipoclorito de sódio por 30 minutos. A seguir a polpa deverá ser removida por cavidade de acesso coronária, o canal preparado de maneira convencional, cuidando-se para que não haja excessivo desgaste das paredes já delgadas pelo incompleto desenvolvimento radicular. Em seguida o dente deverá ser mergulhado em várias soluções, na seguinte seqüência:

1. Solução saturada de ácido cítrico por 3 minutos, seguido de lavagem com soro fisiológico.

2. Solução de fluoreto de estanho (SnF2) a $1 \%$ por 5 minutos.

3. Solução de dicloxacilina $1 \mathrm{mg} / 20 \mathrm{ml}$ por mais 5 minutos.

O canal deverá ser seco com pontas de papel absorvente e obturado de maneira convencional, seguido da restauração da cavidade de acesso. Após estes procedimentos o dente deverá ser reimplantado e confeccionada uma contenção semi-rígida, que deverá permanecer por um período que pode variar entre 10 e 15 dias, esperando que haja o início de uma anquilose, uma vez que inexiste o LPD.

Este protocolo poderia incluir mais um item preconizando a administração de terapêutica sistêmica.

O já clássico trabalho de ANDREASEN et al. ${ }^{24,25,26,27}$, publicado em 1995, nos mostra o controle e acompanhamento de 400 dentes permanentes avulsionados e reimplantados no período compreendido entre 1965 e 1988, com uma média de 5,1 anos de 
acompanhamento em cada caso. As idades variaram entre 5 e 52 anos com média de 13,7 anos. O controle foi padronizado na avaliação clínica, envolvendo testes de mobilidade e radiografias. Deste estudo podemos obter algumas informações importantes como: 8\% dos dentes mantiveram a vitalidade pulpar, 24\% da amostra apresentava o ligamento periodontal normal e 93\% com gengiva normal. Durante o período de avaliação, 30\% dos dentes foram extraídos, sendo maior a perda no grupo que apresentava rizogênese incompleta na época da reimplantação.

ÇALISKAN; TÜRKÜN ${ }^{44}$, numa avaliação publicada em 1995, relataram em seu texto os achados relativos ao levantamento realizado em 1981 e 1993, na cidade de Izmir, Turquia, onde 370 pacientes tiveram 470 dentes traumatizados. Observaram que:

- A incidência é maior em meninos (64,8 \%);

- A faixa etária de maior incidência foi entre 11 e 15 anos (37,4\%);

- $\mathrm{O}$ inciso central superior foi o dente mais afetado (66,2\%);

- A maioria dos traumas foram em decorrência de causas indefinidas $(40,4 \%)$;

- A avulsão de dentes permanentes corresponde a 3,2\% dos casos de traumatismo.

Avaliando clínica e radiograficamente 33 incisivos reimplantados, durante 5 anos, SCHATZ; HAUSHERR; JOHO ${ }^{144}$, também em 1995, obtiveram índice de 66,7\% de normalidade no ligamento periodontal, quando a reimplantação foi realizada até 1 horas após a avulsão. Já os dentes reimplantados após 3 horas, tiveram 83,3\% de reabsorção inflamatória ou por substituição. HAMILTON; HILL; HOLLOWAY $^{72}$, em 1997, estudando 2022 dentes com evidência de trauma em escolares com idades entre 11 e 14 anos, observaram que em 34\% dos 
casos ocorreram traumas superficiais e 12\% necessitaram de algum procedimento clínico, e dentre estes, 59\% receberam tratamento inadequado.

Em função deste resultado, e ainda no mesmo ano, HAMILTON; HILL; MACKIE ${ }^{73}$ resolveram investigar o nível de conhecimento nos casos de avulsão dental, enviando um questionário a professores de educação física, enfermeiras escolares, funcionários que ficam em contato com piscinas, centros de diversão e aos pais de crianças que freqüentam estes locais. Por fim, revelaram que os conhecimentos para tratar os casos de avulsão dental são inadequados tanto pelos funcionários quanto pelos pais . Num total de 459 indivíduos questionados, 53,6\% receberam treinamento sobre acidentes, onde em somente 3,1\% foi citado o trauma dental, $11,5 \%$ dos que tinham conhecimento informaram tê-lo obtido através de cartazes colocados em lojas, ruas e centros comerciais. Mais de $80 \%$ das pessoas não teriam conhecimento para reimplantar seu próprio dente no caso de uma avulsão.

BARRET; KENNY ${ }^{30}$, realizando uma revisão de literatura, publicada em 1997, constataram que inúmeros profissionais que lidam com crianças, não estão preparados para lidar com a avulsão dental.

Mais tarde, SAE-LIM; YUEN ${ }^{139}$, estudando 264 dentes permanentes traumatizados, onde $48 \%$ sofreram avulsão, ressaltaram a importância de publicações com informações sobre as condutas frente aos traumas dentais e também, uma padronização da documentação relativa ao diagnóstico e tratamento, para permitir uma comparação com outros estudos.

Com o objetivo de identificar as variáveis que influenciam a permanência dos dentes reimplantados após longos períodos de permanência extra-alveolar, BARRET; KENNY ${ }^{31}$, publicaram em 1997, 
um levantamento clínico, feito em 38 pacientes que tiveram incisivos permanentes reimplantados. O período extra-alveolar médio foi de 2 horas e o tempo de proservação 2,5 anos, concluindo que dentes com ápice incompleto tiveram um menor tempo de permanência quando comparados aos dentes com ápice totalmente formado. Os dentes que receberam curativo intra-canal de hidróxido de cálcio por pouco tempo ( 7 a 14 dias), e logo foram obturados com guta percha e cimento, permaneceram mais tempo sem reabsorção do que aqueles mantidos durante longo períodos com hidróxido de cálcio, reacendendo a controvérsia sobre o período de utilização daquele curativo.

A questão é saber: deve mesmo a pulpectomia ser realizada de 7 a 14 dias após a reimplantação? A afirmativa a esta pergunta não nos exime entretanto, de uma realidade: a comprovação clínica dos sinais de vitalidade pulpar. Infelizmente, os testes de sensibilidade pulpar correntes, são pobres para indicar a revascularização, cujos resultados levam a remoção desnecessária do tecido conjuntivo pulpar. MESAROS; TROPE ${ }^{112}$, mostraram em 1997, o caso clínico de uma criança com 8 anos de idade, que teve os dois incisivos centrais superiores severamente luxados. Um dos dentes apresentou sensibilidade ao teste térmico frio, 76 dias após o reimplante, o outro não respondeu. Porém, o uso do Laser Doppler indicou a revascularização em ambos os dentes. Este caso demonstra a importância de não ter sido realizada a intervenção endodôntica, antes da sensibilidade pulpar se manifestar, principalmente quando houver uma expectativa de revascularização.

Alguns sinais clínicos deverão ser exaustiva e freqüentemente avaliados: alterações da cor, dor à percussão, presença de mobilidade anormal, e a presença de edema na região apical. 
No final dos anos 90, volta-se a estudar a capacidade de regeneração celular de alguns meios utilizados para transporte e preservação de dentes avulsionados. Com este objetivo, PETTIETTE et al. ${ }^{134}$, em 1997, realizaram pulpectomia e obturação dos canais em 104 raízes de incisivos e pré-molares de cães da raça Beagle. Após os tratamentos endodônticos, os dentes foram cuidadosamente extraídos e divididos em 3 grupos compostos por 32 raízes e 1 grupo com 8 raízes. Este último grupo, considerado o controle negativo, logo após a extração tiveram os dentes imediatamente reimplantadas. Os demais grupos ficaram expostos ao ar livre na ordem que segue: GRUPO I, pelo período de 30 minutos; GRUPO II 45 minutos e o GRUPO III, 60 minutos.

Após este período todos os grupos foram subdivididos em 4 subgrupos de 8 raízes e tratados da seguinte maneira: as raízes de cada subgrupo, após os períodos que permaneceram expostas ao ar, 30, 45 e 60 minutos, foram reimplantadas, constituindo o grupo positivo. Os outros 3 subgrupos, contendo 8 raízes de cada grupo foram, em separado, colocados por um período de 30 minutos, nos seguintes meios reconstituintes: HBBS (Solução Salina Balanceada de Hank’s), VIASPAN (Belzer UW-CSS, DuPont Pharmaceuticals) e um meio condicionador derivado da cultura de fibroblastos de gengiva humana. A análise dos resultados dessa pesquisa permitem tirar algumas conclusões a saber:

- Dentes avulsionados devem ser reimplantados tão logo possível.

- Em 30 minutos de tempo extra-alveolar seco, o percentual de vitalidade do ligamento periodontal foi de $72 \%$, muito próximo dos $89 \%$ quando o reimplante foi imediato. Esta diferença decresce significativamente aos 45 minutos (39\%), atingindo $31 \%$ depois de 60 minutos.

- Quando colocados em soluções reconstituintes por 30 minutos, após ficarem expostos ao ar por 30, 45 e 60 minutos, os melhores resultados 
ficaram com o VIASPAN, que depois da permanência extra-alveolar por mais de 60 minutos, manteve a vitalidade em $61 \%$ das células do ligamento periodontal.

O trabalho realizado por NISHIOKA; SHIIYA; UENO $^{119}$, em 1998, avaliou a influência da infecção bacteriana nos tecidos pulpares e periodontais em dentes reimplantados de ratos germ-free e ratos convencionais. A avaliação histológica dos dentes reimplantados nos ratos convencionais demonstrou uma grande diversidade na resposta do tecido pulpar, como revascularização e necrose pulpar seguida de reabsorção inflamatória. Nos animais germ-free o comportamento do tecido pulpar foi menos variável e com freqüência, apresentaram tecido semelhante a osso e anquilose. Afirmaram estes autores que, a presença de bactérias causa a maioria das complicações após reimplantes, tais como necrose pulpar e reabsorção inflamatória.

Seguindo esta mesma linha de raciocínio, LINDSKOG; PIERCE; BLOMLÖF ${ }^{98}$, em 1998, estudaram a utilização de clorexidina intra-canal, como terapêutica para evitar a reabsorção inflamatória. Incisivos de macacos foram infectados, extraídos, removida a camada de cemento e reimplantados. Após 4 semanas os canais foram preenchidos com gel de clorexidina e os animais sacrificados depois de mais 4 semanas. O exame histológico mostrou que a inflamação e reabsorção periodontal apical e lateral, foi menor nos dentes que receberam a clorexidina.

A utilização de antibioticoterapia sistêmica, como uma etapa importante no tratamento inicial de dentes avulsionados, foi avaliada por SAE-LIM; WANG; TROPE ${ }^{140}$, em 1998, administrando sistemicamente tetraciclina e amoxicilina, em cães que tiveram dentes 
reimplantados e infectados. Após 6 meses os cães foram sacrificados e os dentes preparados para análise histológica. Demonstraram não existir diferença estatística significante na análise de superfícies em reparo e com reabsorção radicular inflamatória, entre os dois antibióticos, mas observaram que a utilização destes fármacos aumentou o índice de superfícies em reparo. Ainda neste ano, SAE-LIM; METZGER; TROPE ${ }^{141}$, pesquisaram a influência de um antiinflamatório (dexametasona), administrado por via sistêmica e aplicado topicamente sobre dentes avulsionados em cães. Notaram diferença estatística significante na reabsorção radicular inflamatória: quando a dexametasona foi aplicada topicamente nos dentes a reabsorção foi menor do que quando utilizada somente pela via sistêmica.

Voltando ao tema do armazenamento de dentes avulsionados, MARINO et al. ${ }^{104}$, em 2000, comparou a capacidade de preservação das fibras do ligamento periodontal, do leite em embalagem tipo longa vida (Parmalat ${ }^{\circledR}$ ), leite pasteurizado e o kit Save-a-Tooth, que contém a solução de Hank's (3M Health Care). Foram utilizadas culturas de células e água como controle. Foi constatado que todos os meios analisados são melhores que a água. Depois de 8 horas, as células foram melhor conservadas nos meios contendo leite do que no Save-a-Tooth. Concluíram que, por não existir diferença entre o leite pasteurizado e o longa vida, o último tem a vantagem de não necessitar refrigeração e assim, é um meio fácil de se encontrar em qualquer lugar.

À vista da literatura consultada, constatamos que há muitas contradições no que concerne ao tratamento inicial do elemento dental avulsionado. 
Nos propusemos, então, a fazer uma análise nos prontuários com histórico de avulsão dental, do Serviço de Urgência Odontológica da Faculdade de Odontologia de Bauru da Universidade de São Paulo, observando os dentes que foram reimplantados ou não, os tratamentos iniciais, proservação instituída e dados epidemiológicos. 


\section{3 - PROPOSIÇÃO}




\section{3 - PROPOSIÇÃO}

Analisar os prontuários de pacientes acidentados, que tiveram dentes avulsionados no período de janeiro de 1983 a dezembro de 2000, observando informações sobre os dados clínicos que correspondem aos tratamentos iniciais e a proservação instituída, bem como os dados epidemiológicos. 


\section{4 - MATERIAL E MÉTODOS}




\section{4 - MATERIAL E MÉTODOS}

A amostra deste estudo foi obtida através da análise de 64.788 prontuários de atendimento do Serviço de Urgência Odontológica da Faculdade de Odontologia de Bauru da Universidade de São Paulo, no período de janeiro de 1983 a dezembro de 2000. Foram selecionados para este estudo, 87 prontuários de pacientes que sofreram avulsão traumática de dentes permanentes, coletando dados clínicos (tratamentos iniciais e proservação instituída) e dados epidemiológicos:

- TRATAMENTOS INICIAIS:

$\checkmark$ Tempo de permanência extra-alveolar

$\checkmark$ Meio usado na conservação do dente avulsionado

$\checkmark$ Preparo do alvéolo

$\checkmark$ Tratamento da superfície radicular

$\checkmark$ Tipo de contenção empregado

$\checkmark$ Medicação sistêmica

- PROSERVAÇÃo INSTITUÍdA

- DADOS EPIDEMIOLÓGICOS:

$\checkmark$ Elementos dentais mais atingidos

$\checkmark$ Idade do paciente na época da reimplantação

$\checkmark$ Sexo

$\checkmark$ Raça

$\checkmark$ Tipo de acidente

$\checkmark$ Ambiente de ocorrência

$\checkmark$ Distribuição dos acidentes no período analisado

$\checkmark$ Distribuição dos acidentes na estação do ano

$\checkmark$ Número de dentes avulsionados por paciente 
Os pacientes que tiveram os dentes reimplantados, num total de 52, não estavam sob proservação e foram convidados a colaborar para uma avaliação clínica e radiográfica dos dentes reimplantados e os pacientes sob proservação, num total de 22, já tinham em seus prontuários os resultados recentes da avaliação clínica e radiográfica. Durante a avaliação clínica procurou-se observar os seguintes aspectos: alteração cromática da coroa dental, posicionamento do dente na arcada, recessão gengival, presença de fístula, grau de mobilidade, anquilose, alinhamento da borda incisal e testes de sensibilidade pulpar naqueles casos onde existia expectativa de revascularização pulpar.

Após o exame clínico, foi realizada uma radiografia periapical com a finalidade de verificar a presença de periapicopatias, reabsorção radicular e o estágio de desenvolvimento da raiz.

O exame clínico associado ao exame radiográfico permitiu classificar o resultado do reimplante do dente avulsionado em: completo, aceitável e fracasso.

Os dados obtidos no prontuário e na avaliação do paciente foram tabulados, constituindo valores numéricos e percentuais, apresentados em forma de tabelas e gráficos. 


\section{5 - RESULTADOS}

A demonstração dos resultados será feita por meio de gráficos e tabelas, obedecendo a seqüência de dados contidos em material e métodos.

Tabela 1 - Pacientes acidentados com avulsão traumática de dentes permanentes

\begin{tabular}{c|c|c}
\hline \multicolumn{1}{c|}{ ATENDIMENTOS } & $\mathbf{N}^{\circ}$. PACIENTES & $\mathbf{N}^{\circ}$. DENTES \\
\hline \hline Avulsão e reimplantação & 74 & 101 \\
\hline $\begin{array}{c}\text { Reimplantação não indicada } \\
\begin{array}{c}\text { Reimplantação não executada } \\
\text { (dentes perdidos) }\end{array}\end{array}$ & 3 & 3 \\
\hline TOTAIS & $\mathbf{8 7}$ & 12 \\
\hline
\end{tabular}

\section{1 - Tratamentos iniciais}

Tabela 2 - Tempo de permanência extra-alveolar

\begin{tabular}{c|c}
\hline TEMPO & $\mathbf{N}^{\mathbf{O}}$. DE DENTES \\
\hline \hline Até 30 minutos & 18 \\
\hline Até 1 hora & 9 \\
\hline Até 3 horas & 16 \\
\hline Mais de 3 horas & 9 \\
\hline Mais de 12 horas & 3 \\
\hline Mais de 24 horas & 4 \\
\hline Mais de 48 horas & 2 \\
\hline Mais de 96 horas & 1 \\
\hline Casos sem informação & 39 \\
\hline TOTAL & $\mathbf{1 0 1}$ \\
\hline
\end{tabular}


Tabela 3 - Meios usados na conservação dos dentes

\begin{tabular}{c|c}
\hline $\begin{array}{c}\text { MEIO DE } \\
\text { CONSERVAÇÃo }\end{array}$ & $\mathbf{N}^{\mathbf{0}}$. DE DENTES \\
\hline \hline Leite & 21 \\
\hline Nenhum & 15 \\
\hline Soro Fisiológico & 17 \\
\hline Água & 5 \\
\hline Água e sal & 1 \\
\hline Álcool & 2 \\
\hline Solução de Milton & 1 \\
\hline Casos sem informação & 39 \\
\hline TOTAL & $\mathbf{1 0 1}$ \\
\hline
\end{tabular}

- Preparo do alvéolo: A totalidade dos casos onde o reimplante foi realizado, teve o alvéolo irrigado com soro fisiológico para remoção do coágulo sangüíneo.

- Tratamento da superfície radicular: O único tratamento empregado sobre a superfície radicular, foram borrifos de água. 
Figura 1 - Representação gráfica do número de pacientes e os tipos de contenção empregados

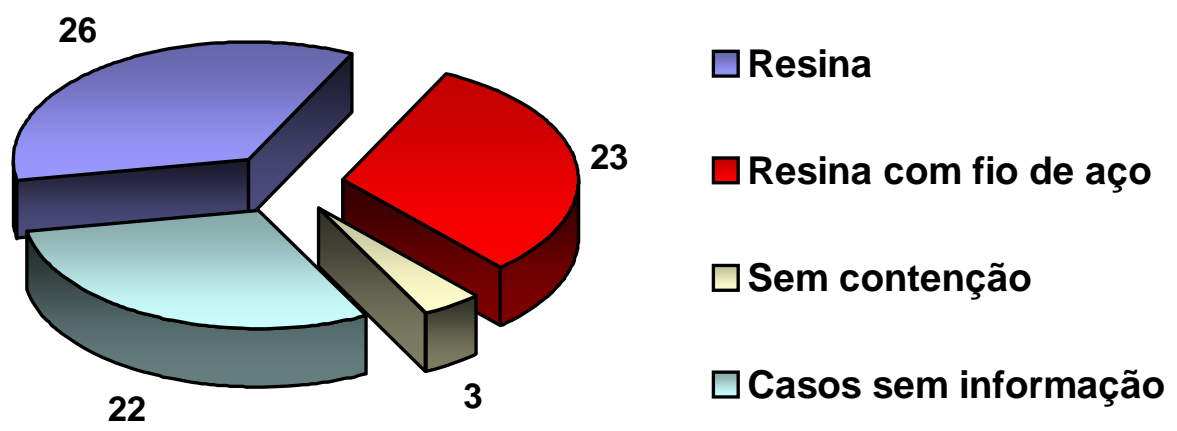

Tabela 4 - Medicação sistêmica prescrita

\begin{tabular}{l|c|c}
$\begin{array}{c}\text { DROGAS } \\
\text { UTILIZADAS }\end{array}$ & $\begin{array}{c}\text { POSOLOGIA } \\
\text { INFANTIL }\end{array}$ & $\begin{array}{c}\text { POSOLOGIA } \\
\text { ADULTO }\end{array}$ \\
\hline \hline Ampicilina & $250 \mathrm{mg}$ & $500 \mathrm{mg}$ \\
& $6 \mathrm{em} 6$ horas & $6 \mathrm{em} 6$ horas \\
& $7 \mathrm{dias}$ & $7 \mathrm{dias}$ \\
\hline Estolato de & $250 \mathrm{mg}$ & $500 \mathrm{mg}$ \\
eritromicina ${ }^{*}$ ) & $8 \mathrm{em} 8$ horas & $12 \mathrm{em} 12$ horas \\
& 7 dias & 7 dias \\
\hline
\end{tabular}

(*) Indicado para pacientes alérgicos às penicilinas 


\section{2 - Proservação instituída}

Tabela 5 - Procedimentos endodônticos realizados

\begin{tabular}{l|c|c|c|c|c}
\hline \multirow{2}{*}{ PROCEDIMENTO } & \multicolumn{5}{|c}{ TEMPO } \\
\cline { 2 - 6 } & 7 dias & 14 dias & +14 dias & 1 ano & 2 anos \\
\hline \hline Pulpectomia & 52 & 18 & 3 & - & 1 \\
\hline $\begin{array}{c}\text { Curativo intra-canal } \\
\mathrm{Ca}(\mathrm{OH})_{2}\end{array}$ & - & - & - & 36 & 38 \\
\hline
\end{tabular}

\section{3 - Dados epidemiológicos}

Figura 2 - Representação gráfica dos dentes avulsionados (quantidade e percentual)

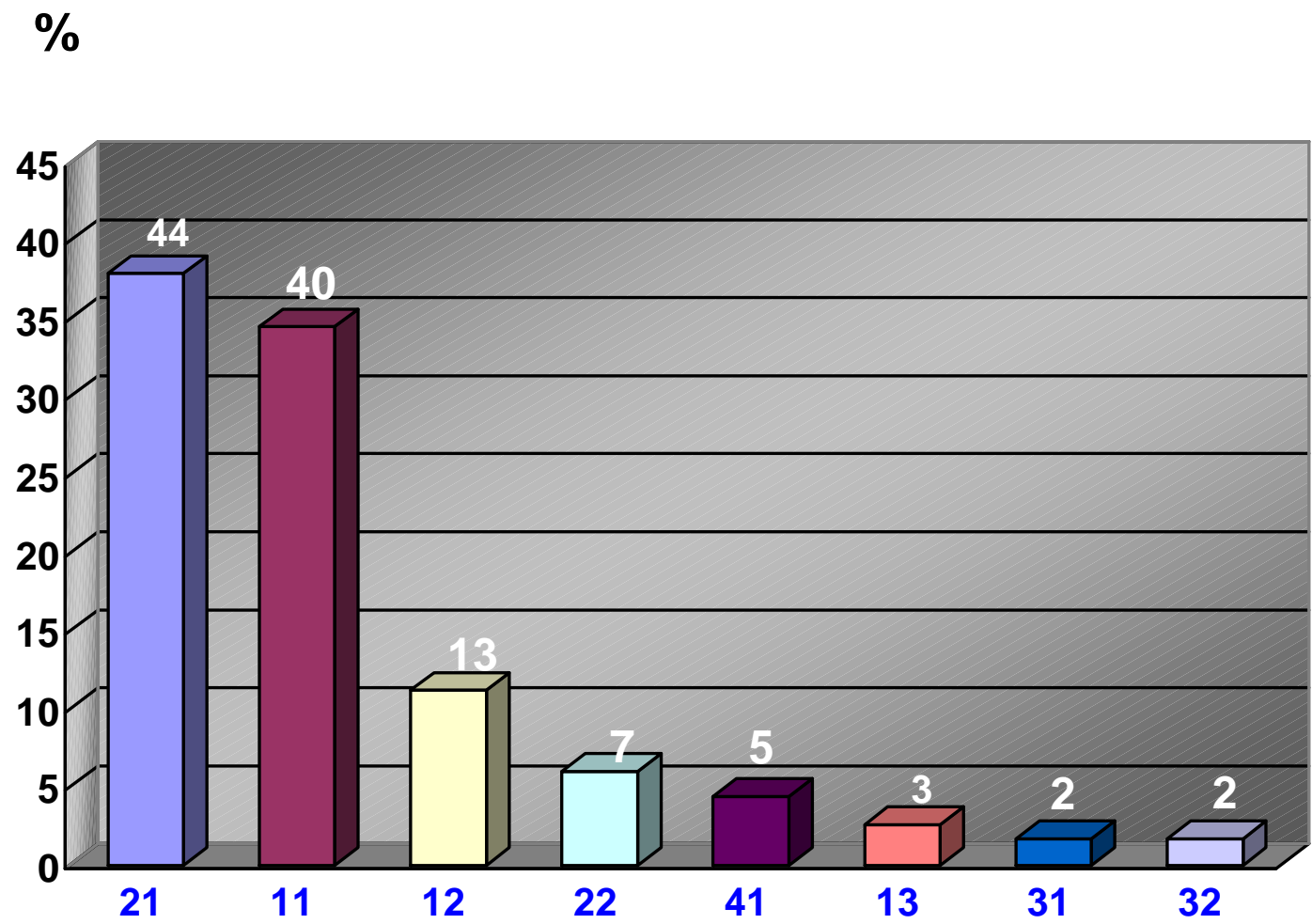

dente 
Tabela 6 - Idade dos pacientes na avulsão

\begin{tabular}{c|c}
\hline IDADE EM ANOS & $\mathbf{N}^{\circ}$ DE CASOS \\
\hline \hline 6 & 3 \\
\hline 7 & 4 \\
\hline 8 & 14 \\
\hline 9 & 6 \\
\hline 10 & 9 \\
\hline 11 & 7 \\
\hline 12 & 7 \\
\hline 13 & 5 \\
\hline 14 & 8 \\
\hline 15 & 3 \\
\hline 16 & 4 \\
\hline 17 & 4 \\
\hline 18 & 4 \\
\hline 20 & 2 \\
\hline 21 & 2 \\
\hline 22 & 1 \\
\hline 25 & 1 \\
\hline 30 & 1 \\
\hline 33 & 1 \\
\hline 38 & 1 \\
\hline
\end{tabular}

Figura 3 - Representação gráfica da incidência por sexo

Masculino - 53 pacientes

Feminino -34 pacientes

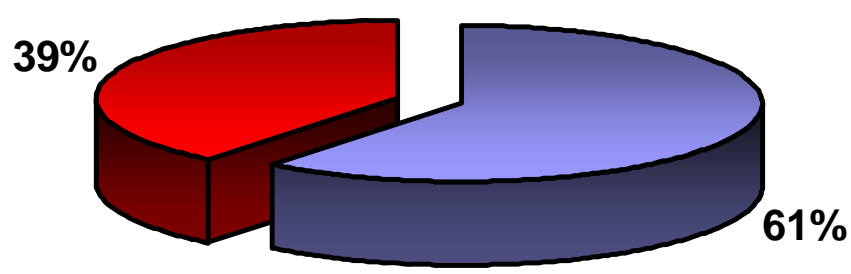


Figura 4 - Representação gráfica da incidência por raça

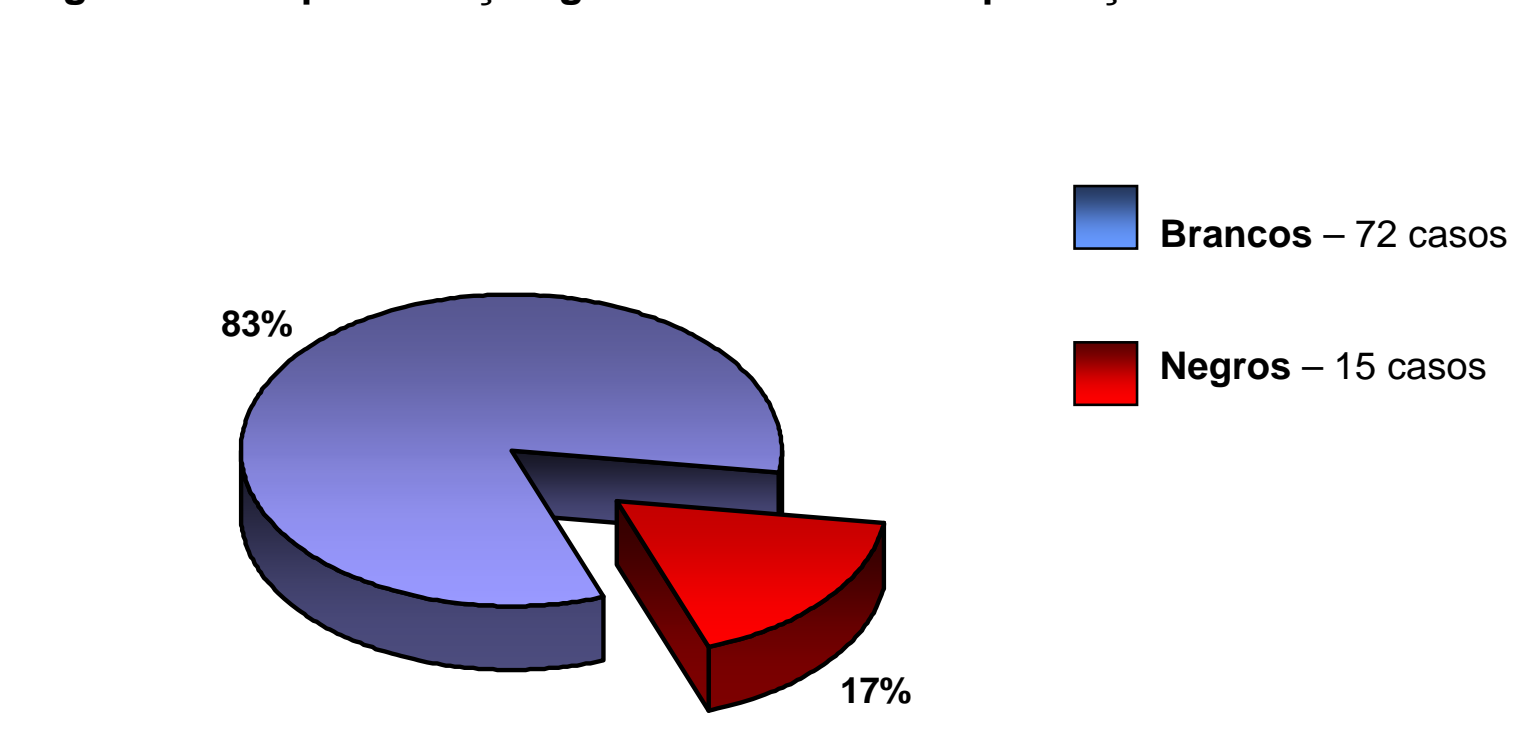

Tabela 7 - Tipo de acidente

\begin{tabular}{l|c}
\hline \multicolumn{1}{c|}{ CAUSA } & No. DE CASOS $^{\circ}$ \\
\hline \hline Queda acidental & 25 \\
\hline Bicicleta & 11 \\
\hline Agressão & 5 \\
\hline Atropelamento & 4 \\
\hline Acidente automobilístico & 4 \\
\hline Prática esportiva & 2 \\
\hline Casos sem informação & 36 \\
\hline
\end{tabular}

Tabela 8 - Ambiente de ocorrência

\begin{tabular}{l|c}
\multicolumn{1}{c|}{ AMBIENTE } & No. DE CASOS $^{\circ}$ \\
\hline \hline Residência & 23 \\
\hline Escola & 9 \\
\hline Piscina & 3 \\
\hline Sem Informação & 52 \\
\hline
\end{tabular}


Resultados 54

\section{Tabela 9 - Distribuição dos acidentes no período analisado}

\begin{tabular}{|c|c|c|c|c|c|c|c|c|c|c|c|c|c|c|c|c|c|c|c|}
\hline \multirow{2}{*}{ MÊS } & \multicolumn{19}{|c|}{ ANO } \\
\hline & 1983 & 1984 & 1985 & 1986 & 1987 & 1988 & 1989 & 1990 & 1991 & 1992 & 1993 & 1994 & 1995 & 1996 & 1997 & 1998 & 1999 & 2000 & TOTAL \\
\hline Janeiro & 1 & & & & & & & & 1 & & 2 & & & & & & & & 4 \\
\hline Fevereiro & & & & & & 1 & & & & 1 & & & & & & & & & 2 \\
\hline Março & & 1 & & & & & & & 1 & 2 & & & & 1 & 1 & 1 & 1 & & 8 \\
\hline Abril & & & 1 & & & 1 & & 2 & & 2 & 2 & 1 & & 1 & 1 & & & & 11 \\
\hline Maio & & & & & & & & 2 & 2 & 1 & 1 & & & & & & & & 6 \\
\hline Junho & & 1 & & & 1 & 1 & 2 & & & 1 & 1 & & 1 & 1 & 2 & & 2 & & 13 \\
\hline Julho & & & & & & & 1 & & 1 & & & & 1 & & 2 & & & & 5 \\
\hline Agosto & & 1 & & & & & 1 & & 1 & & & & 2 & 1 & 1 & 1 & & & 8 \\
\hline Setembro & 1 & & & 1 & & 1 & & & & & 2 & 1 & & 1 & & 1 & & & 8 \\
\hline Outubro & & 1 & & 1 & & & & 1 & & 1 & 1 & & 1 & & 2 & & 1 & & 9 \\
\hline Novembro & & 1 & & & & & & & & & 1 & & 1 & & 1 & & 2 & & 6 \\
\hline Dezembro & & & & 1 & & & & 2 & 1 & & & & & & 2 & 1 & & & 7 \\
\hline TOTAL & 2 & 5 & 1 & 3 & 1 & 4 & 4 & 7 & 7 & 8 & 10 & 2 & 6 & 5 & 12 & 4 & 6 & 0 & 87 \\
\hline
\end{tabular}


Figura 5 - Representação gráfica do percentual e número de dentes avulsionados por paciente

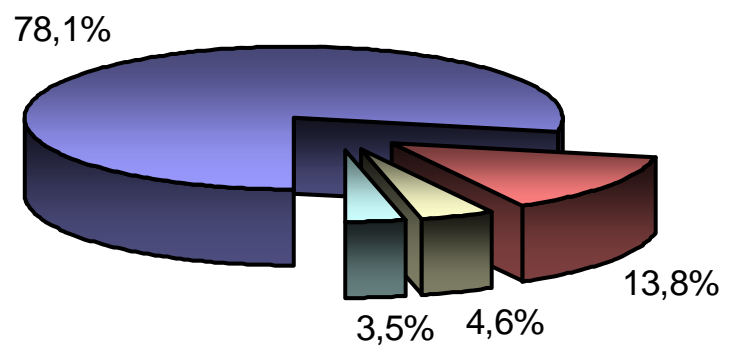

$\square$ - 68 pacientes com 1dente avulsionado - 78,1\%

$\square$ \& 12 pacientes com 2 dentes avulsionados - 13,8 \%

$\square: 4$ pacientes com 3 dentes avulsionados - 4,6\%

$\square<3$ pacientes com 4 dentes avulsionados - 3,5\%

Figura 6 - Representação gráfica do número de casos em função da época do ano

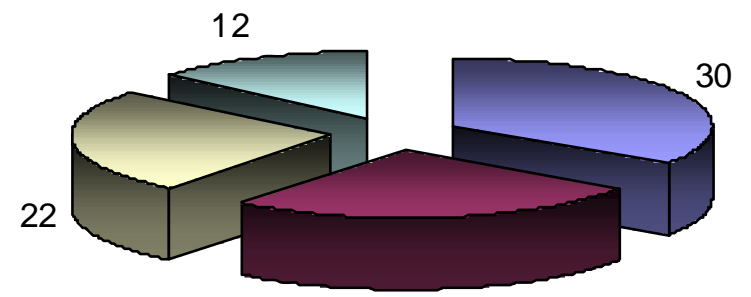

23

$\square$ Outono - 30 casos - $34,5 \%$

Inverno - 23 casos - $26,4 \%$

Primavera - 22 casos - 25,3\%

Verão - 12 casos - 13,8 \% 
Tabela 10 - Resultado do reimplante em função do tempo extra-alveolar

\begin{tabular}{l|c|c|c|c|c|c|c}
\hline \multirow{2}{*}{$\begin{array}{c}\text { CONSEQÜÊNCIA } \\
\text { DO } \\
\text { TRATAMENTO }\end{array}$} & \multicolumn{2}{|c|}{$\begin{array}{c}\text { DENTES } \\
\text { REIMPLANTADOS }\end{array}$} & \multicolumn{5}{|c}{ TEMPO ENTRE A AVULSÃO E O REIMPLANTE } \\
\cline { 2 - 8 } ( EM MINUTOS )
\end{tabular}

Tabela 11 - Resultado do reimplante em função dos meios de conservação que foram mais utilizados

\begin{tabular}{l|c|c|c|c|c}
\hline \multirow{2}{*}{$\begin{array}{c}\text { CONSEQÜÊNCIA } \\
\text { DO } \\
\text { TRATAMENTO }\end{array}$} & \multicolumn{2}{|c|}{ DENTES } & \multicolumn{3}{|c}{ MEIO DE CONSERVAÇÃO } \\
\cline { 2 - 6 } & NE & $\%$ & LEITE & SECO & SORO \\
\hline \hline $\begin{array}{l}\text { Sucesso } \\
\text { completo }\end{array}$ & 16 & 45,7 & 13 & 2 & 1 \\
\hline $\begin{array}{l}\text { Sucesso } \\
\text { aceitável }\end{array}$ & 4 & 11,4 & 3 & 1 & 0 \\
\hline Fracasso & 15 & 42,9 & 1 & 12 & 2 \\
\hline
\end{tabular}


6 - DISCUSSÃO 


\section{6 - DISCUSSÃO}

Os reimplantes de dentes permanentes avulsionados acidentalmente, são descritos há muito tempo na literatura através de relatos clínicos e publicações mostrando resultados retrospectivos em humanos, bem como estudos experimentais em animais, todavia as opiniões são contraditórias, principalmente no que concerne ao tratamento inicial. Em vista disso, o objetivo deste trabalho foi coletar e analisar dados referentes aos tratamentos clínicos iniciais, proservação e incidência das avulsões dentais.

\section{1 - Discussão da Metodologia}

\subsection{1 - Seleção da amostra}

Este estudo retrospectivo foi conduzido no Serviço de Urgência Odontológica da Faculdade de Odontologia de Bauru da Universidade de São Paulo. No período compreendido entre janeiro de 1983 e dezembro de 2000, foram atendidos naquele serviço 87 pacientes acidentados, envolvendo um total de 116 dentes permanentes avulsionados ( Tabela 1).

Pela análise dos prontuários foram coletados os dados referentes aos tratamentos iniciais: meio utilizado na conservação do dente avulsionado, preparo do alvéolo, tratamento da superfície radicular, tipo de contenção empregado, medicação sistêmica prescrita e a proservação instituída em cada caso. Ainda com base nestes prontuários, buscou-se informações relativas aos dados epidemiológicos: elementos dentais mais atingidos, idade do paciente na época da reimplantação, sexo, raça, tipo de acidente, ambiente de ocorrência, distribuição dos acidentes no período analisado e estações do ano, assim como o número de dentes avulsionados por paciente. 
A seqüência de dados que compreende os tratamentos iniciais e a proservação instituída, estavam contidos nos referidos prontuários. Com referência aos dados epidemiológicos, a coleta daquelas informações é uma constante na literatura ${ }^{9,13,71,78,88,97,103,122,144}$, quando se faz um levantamento dessa natureza.

Para este estudo ficou determinado também que o tempo mínimo decorrido entre o reimplante e esta investigação foi de 1 ano. Os pacientes foram convidados para uma avaliação clínica e radiográfica durante os meses de novembro e dezembro de 2000, com exceção daqueles que já relatavam a perda do elemento dental.

\subsection{2 - Avaliação clínica e radiográfica}

Durante o exame clínico dos dentes reimplantados, foi dado ênfase aos aspectos relativos à anquilose, sendo considerados como anquilosados os elementos dentais que não apresentavam mobilidade fisiológica $^{93}$ e, o som durante a manobra de percussão era diferente do dente adjacente. Esse mesmo som é descrito como "metálico" por ANDERSSON et al. $^{6}$ e ANDREASEN ${ }^{16}$. A infra-oclusão, que determina o desalinhamento da borda incisal, foi registrada quando não coincidia com o plano oclusal e, o aspecto estético era insatisfatório (MACKIE; WORTHINGTON ${ }^{102,103}$ e KAWANAMI et al. ${ }^{87}$ ), conforme o caso clínico ilustrado na Figura 7.

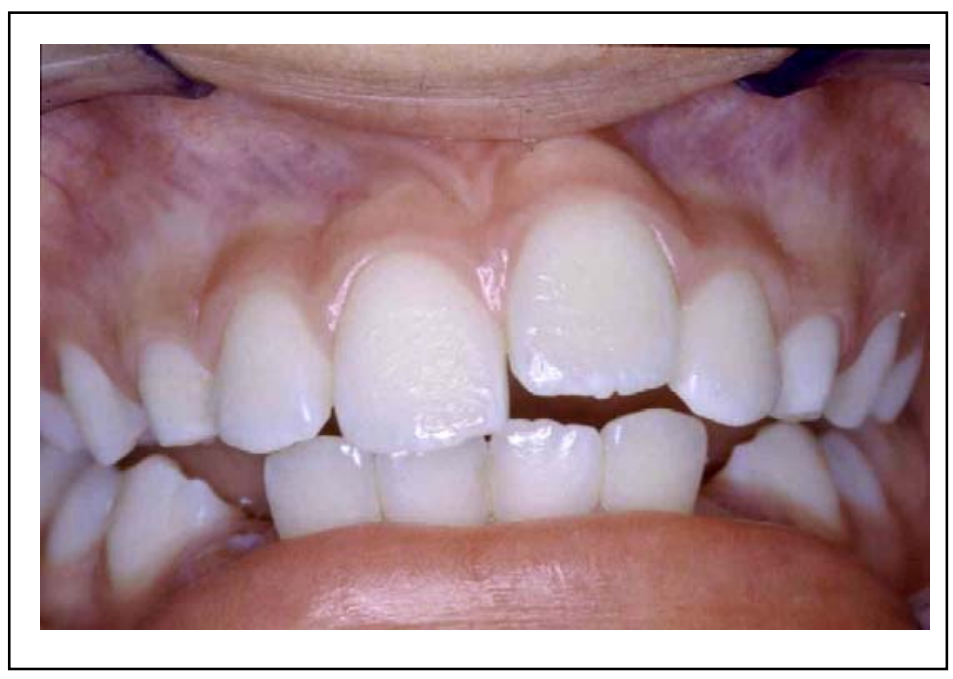

Figura 7 - Dente 21 em infra-oclusão (anquilose) 
A vitalidade pulpar daqueles dentes que não receberam intervenção endodôntica, foi avaliada pela estimulação térmica usando-se cloreto de etila. Quando a resposta a este teste era positiva e, a radiografia mostrava continuação do desenvolvimento radicular desde a época da reimplantação, a polpa era considerada como vital.

A análise da imagem radiográfica periapical tomada por ocasião da avaliação clínica, tinha como objetivo verificar a presença de periapicopatias, reabsorção radicular e o estágio de desenvolvimento da raiz.

Exploramos a imagem radiográfica dentro do que ela, limitada em sua natureza, poderia nos oferecer, concordando com a afirmação de ANDREASEN et al. ${ }^{13}$, ao dizer que as técnicas radiográficas convencionais não são meios adequados para diagnosticar cavidades de reabsorção em estágios iniciais, opinião confirmada por FERLINI Fo ${ }^{61}$ em 1999, na sua tese de doutorado. Perda de definição no contorno da lâmina dura e zona radiolúcida na região periapical, nos permite inferir como sendo presença de periapicopatia; em caso de dúvida a patologia foi considerada como ausente. A reabsorção radicular foi diagnosticada quando a radiografia mostrava uma perda definida de tecido mineralizado da raiz, quando comparada àquela tomada na época do reimplante.

Outro aspecto analisado foi o estágio de desenvolvimento radicular, utilizando-se dois critérios: dentes com rizogênese completa ou incompleta. O conjunto de informações de ordem clínica e radiográfica nos permitiu classificar o resultado da reimplantação dental em sucesso completo e aceitável ou fracasso conforme MACKIE; WORTHINGTON ${ }^{102,103}$, que comungam com a metodologia adotada neste trabalho, ou seja, uma avaliação puramente qualitativa. 
- COMPLETO: quando clinicamente não se observava sinais de anquilose, infra-oclusão ou infecção e, radiograficamente ausência de reabsorção radicular e patologia periapical (Figura 8A).

- ACEITÁVEL: dente ainda presente na cavidade bucal, funcional, sem sinais de infecção visíveis clínica e radiograficamente mas, mostrando evidência de reabsorção radicular controlada ou atenuada (Figura 8B).

- FRACASSO: quando na época deste estudo o dente já fora extraído, ou com exodontia indicada (Figura 8C).

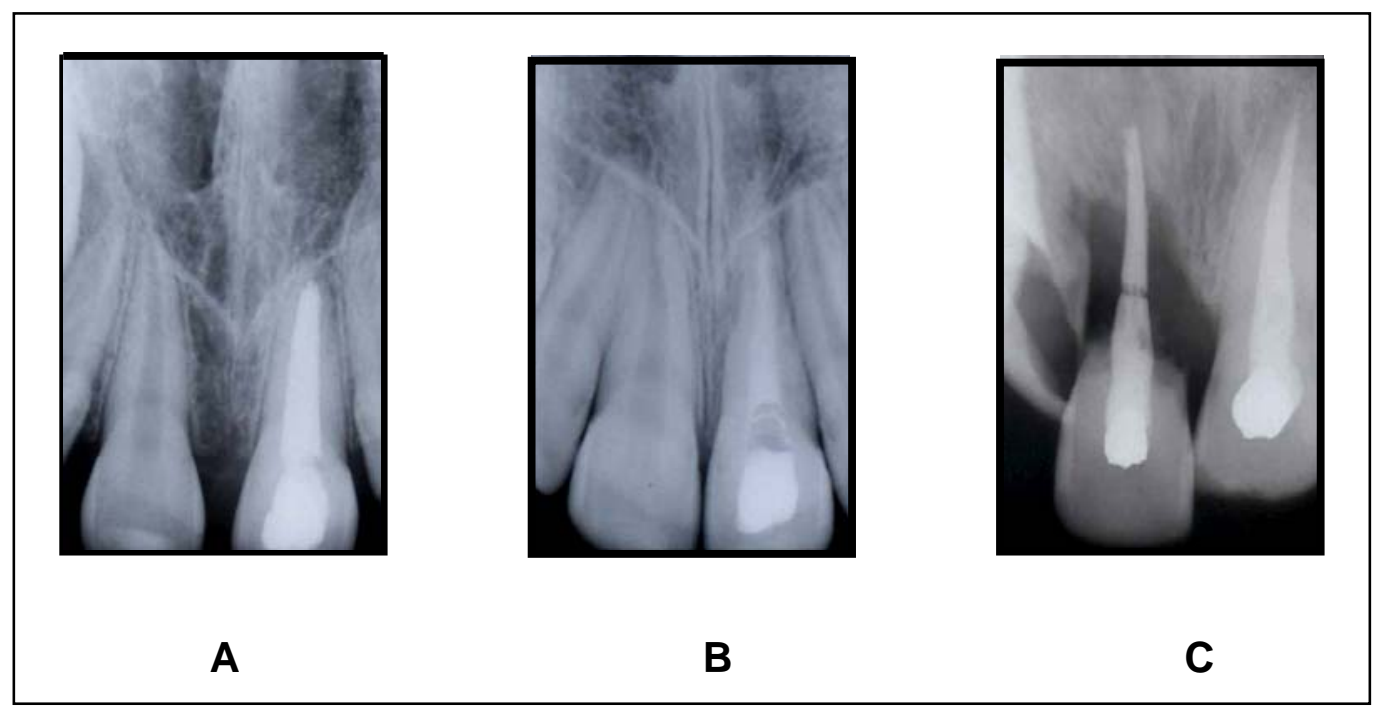

Figura 8 - Imagens radiográficas que caracterizam o resultado da reimplantação: A - Completo; B - Aceitável; C - Fracasso

\section{2 - Discussão dos Resultados}

\subsection{1 - Tempo de permanência extra-alveolar}

Um fator fundamental no sucesso de reimplantes é o tempo de permanência extra-alveolar ${ }^{8,9,78,154}$, ANDREASEN ${ }^{18}$ recomenda que se reimplante o dente o mais rápido possível. Na nossa amostra observamos que 12 elementos dentais foram reimplantados dentro de 30 minutos, tempo considerado limítrofe para manutenção da vitalidade das células do ligamento periodontal, desde que acondicionados em meio líquido adequado ${ }^{8,78,108}$. 
A literatura clínica sobre avulsão e reimplantação é dominada por relatos clínicos isolados e muito pobre em estudos retrospectivos, que são realizados com metodologias de avaliação diferentes. Fazer uma comparação entre estes estudos é muito difícil pela variação dos critérios usados para avaliar o resultado do tratamento ou protocolo empregados. "Sucesso" é o termo comumente utilizado nestes estudos quando o dente reimplantado esta livre de seqüelas indesejáveis (anquilose, infra-oclusão, reabsorção, periapicopatias). “Sobrevivência” , com freqüência é impropriamente utilizado como sinônimo de sucesso, porém, deve ser entendido como o tempo que o dente reimplantado permaneceu em função mastigatória, ou melhor, aquele intervalo de tempo decorrido entre a reimplantação e a perda do dente.

A definição de sucesso deve ser vista com cautela, uma vez que, sua mensuração é subjetiva e inconsistentemente definida. Qual seria então o tempo de sobrevida do dente reimplantado para caracterizar o sucesso? Não encontramos resposta na literatura.

Uma das primeiras tentativas para avaliar a conseqüência dos reimplantes foi realizada por LENSTRUP; SKIELLER ${ }^{97}$, que avaliando 46 dentes reimplantados observaram sobrevivência em 57\% dos casos, porém, não relacionaram este resultado com o tempo de permanência extra-alveolar.

Nosso critério de avaliação permite uma comparação com os resultados de ANDREASEN; HJÖRTING-HANSEN ${ }^{13}$, que nos mostraram $41 \%$ dos dentes reimplantados em até 30 minutos, sem sinais de reabsorção, nosso estudou encontrou 43,2 \%, bem como GONDA et al. ${ }^{66}$, que apresentaram 44,0\%, também reimplantados em até 30 minutos, o percentual mais baixo encontrado em reimplantação até 30 minutos foi de 
30,0\%, apresentado por MACKIE; WORTHINGTON ${ }^{102}$, sem nenhuma evidência de reabsorção radicular.

ANDREASEN; BODIN ${ }^{9}$, acompanharam clínica e radiograficamente, durante 5 anos, 21 dentes reimplantados com tempo de permanência extra-alveolar inferior a 15 minutos, relatando ser de 100\% o índice de sucesso. Posteriormente ANDREASEN et al. ${ }^{24,25,26,27}$, numa seqüência de publicações onde mostram a influência de diferentes variáveis no sucesso de reimplantes, relatam $73 \%$ de sucesso nos reimplantes realizados em até 5 minutos.

Dos resultados relativos ao tempo de permanência extra-alveolar, expressos na Tabela 2, podemos tirar algumas considerações:

1. Os pacientes que tiveram seus dentes reimplantados até 1 hora após a avulsão, foi em decorrência da dificuldade de locomoção entre o local do acidente até o Serviço de Urgência.

2. Aqueles enquadrados no período com mais de 1 hora e até 48 horas, desconheciam a possibilidade de reimplantação do dente avulsionado, tendo alguns pacientes retornado ao local do acidente para localizar o dente.

3. Apenas 1 caso teve o reimplante realizado após 96 horas, período que o paciente ficou hospitalizado para tratamento de fraturas nos ossos da face.

Observando a conduta de alguns pacientes, concordamos com ÇALISKAN: TURKUN ${ }^{44}$; HAMILTON; HILL; MACKIE $^{73}$; RAPHAEL; GREGORY ${ }^{137}$ e SAE-LIM; YUEN ${ }^{139}$, que investigando o nível de conhecimento sobre o manuseio de dentes avulsionados, tanto pelo público leigo como profissionais de saúde, concluíram pela necessidade de mais programas educativos sobre a importância do imediato atendimento e conservação do dente. Entretanto, 
deparamo-nos com resultados surpreendentes, como ilustrado na Figura 9, onde o elemento 21 foi reimplantado depois de mantido, inadequadamente, seco por mais de 96 horas e permaneceu funcional por mais de 2 anos, quando iniciou-se um processo de reabsorção inflamatória na região cervical. Relatos desta natureza são encontrados na literatura como os de ABRAMS $^{1}$, ÇALISKAN ${ }^{45}$, DUGGAL ${ }^{57}$ e MENEZES $^{111}$.

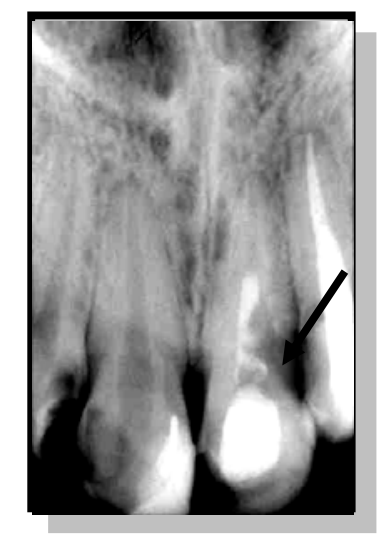

Figura 9 - Dente 21 reimplantado depois de 96 horas (controle radiográfico de 2 anos)

\subsection{2 - Meio usado na conservação do dente}

A imediata reimplantação do dente avulsionado é o procedimento ideal para conseguir um reparo do ligamento periodontal. Quando isso não é possível, se torna imperativo a necessidade de mantermos a vitalidade das células remanescentes na superfície radicular. Essa manutenção é conseguida por vários meios de armazenamento já estudados como: saliva, soro fisiológico, leite, água, meios de cultura, invólucro plástico, congelamento e substâncias usadas na preservação de órgãos a serem transplantados, conforme trabalhos de BLOMLÖF; OTTESKOG $^{36}$, BLOMLÖF et al. ${ }^{37,38,39}$, ANDREASEN; SCHWARTZ ${ }^{22}$, HILTZ;TROPE ${ }^{81}$, HAMMARSTRÖM et al. ${ }^{74}$.

A afirmativa de ANDREASEN et al. ${ }^{27}$, que o meio de conservação é mais importante que o tempo de permanência extra-alveolar, permite uma dedução contraditória à primeira vista, partindo do 
pressuposto inegável que o dente avulsionado deve ser reimplantado, se possível, imediatamente. Essa possibilidade nem sempre ocorre, então, a utilização de um meio de conservação adequado assume uma importância preponderante, mas nem sempre é possível obtê-lo no momento do acidente. Por outro lado, nos deparamos com a questão no nível de conhecimento por parte do público leigo e principalmente daqueles que lidam diretamente com crianças ${ }^{44,73,137}$, pois, a escolha do meio para conservação e transporte do dente avulsionado, nem sempre é determinada pelo profissional de odontologia.

Felizmente, a maioria dos pacientes que compuseram nossa amostra optou pelo leite como meio de conservação, (Tabela 3). Os estudos de BLOMLÖF et al. ${ }^{37,38,39}$ nos mostraram que o leite, pela sua relativa osmolaridade fisiológica, é capaz de manter a vitalidade das células do ligamento periodontal remanescente na superfície radicular por até 3 horas, tempo normalmente suficiente para o acidentado buscar atendimento adequado. Posteriormente, HILTZ; TROPE ${ }^{72}$ comparando in vitro leite, solução de Hank's e Viaspan, observaram que o leite manteve a vitalidade de 68,2 \% das células, após um período de 6 horas, com uma grande vantagem sobre os demais meios, pois é usualmente encontrado próximo ao local do acidente. Ainda em relação ao leite, um estudo recente de MARINO et al. ${ }^{104}$, in vitro, mostra que o leite na embalagem do tipo longa-vida foi mais efetivo que a solução de Hank, por não necessitar de refrigeração.

\subsection{3 - Preparo do alvéolo}

Nosso estudo não tem condições de emitir opinião sobre a influência da remoção ou não do coágulo sangüíneo, presente no alvéolo, sobre o sucesso do reimplante, considerando que a remoção do coágulo com curatagem suave coadjuvada pela irrigação abundante com soro 
fisiológico, é um procedimento de rotina para a reimplantação dental no Serviço de Urgência Odontológica da Faculdade de Odontologia de BauruUSP.

Os poucos trabalhos que abordam o tema são contraditórios, ANDREASEN ${ }^{18}$ não encontrou diferença estatisticamente significante quando realizou reimplante intencional em macacos, com e sem a remoção prévia do coágulo sangüíneo, acrescentando que sua permanência exige uma maior pressão para reposicionamento do dente, manobra que pode levar a uma maior injúria em porções vitais do ligamento periodontal. Uma preocupação com relação à curetagem do alvéolo, seria a promoção de danos ao ligamento periodontal remanescente nas paredes ósseas, porém, o próprio ANDREASEN ${ }^{19}$, num estudo posterior, também realizado em animais, removeu aquelas fibras remanescentes no alvéolo através de curetagem, não observando influência no processo de reparação periodontal, afirmando ainda: "a presença de ligamento periodontal viável na superfície radicular é o fator mais importante para assegurar o reparo". Essa afirmativa fundamenta a opinião de OSWALD; HARRINGTON; VAN HASSEL ${ }^{130}$ e VAN HASSEL; OSWALD; HARRINGTON ${ }^{162}$, que demonstraram ser os dois grupos de fibras remanescentes (aquelas aderidas na superfície radicular e no osso alveolar), importantes para o processo de reparo do ligamento periodontal.

Nesse sentido, MATSSON; KLINGE; HALLSTRÖM $^{109}$, adicionaram mais uma variável neste quesito, demonstrando que a remoção do coágulo coadjuvada com irrigação do alvéolo, utilizando soro fisiológico, proporcionou melhores resultados em reimplantes experimentais em cães. A proposta dos referidos autores encontra ressonância nos trabalhos de ANDREASEN ${ }^{18,19}$, onde está demonstrado que o coágulo impede um íntimo contado da superfície 
radicular com a parede alveolar, situação desejável para ocorrência do reparo e, mais ainda, o coágulo é rico em células mononucleadas (monócitos principalmente), que são precursoras das células gigantes multinucleadas responsáveis pela reabsorção radicular ${ }^{109}$. Também é importante esclarecer que a ocorrência de fratura alveolar, e até mesmo presença de fragmentos ósseos no interior do alvéolo podem ser mascaradas pelo coágulo sangüíneo, antecipando o desenvolvimento da reabsorção radicular, justificando dessa maneira a sua remoção ${ }^{66}$. ANDREASEN; HJÖRTING-HANSEN ${ }^{13}$, relataram a ocorrência de reabsorção radicular em todos os casos onde havia a presença de fratura alveolar.

\subsection{4 - Tratamento da superfície radicular}

Os fatores responsáveis pelo fracasso da reimplantação de dentes avulsionados, já foram completamente avaliados e algumas pesquisas mostram claramente procedimentos para aumentar os níveis de sucesso, principalmente quando o dente avulsionado permaneceu por um longo período fora do seu alvéolo. Nesse estudo, constatamos que o único tratamento aplicado sobre a superfície radicular, foi a limpeza com borrifos de água, cuja finalidade era remover qualquer corpo estranho que estivesse ali presente, independente do tempo de permanência extra-alveolar e do

meio de conservação utilizado. À primeira vista, isto nos pareceu uma falha grave, porém, observando atentamente a literatura, pudemos concluir que esta conduta se baseia no seguinte conceito: “ reimplantar o dente avulsionado o mais rápido possível após sua avulsão”. Esta filosofia é derivada das pesquisas de ANDREASEN; HJÖRTING-HANSEN ${ }^{13,14}$, onde estes autores afirmam que os melhores resultados são obtidos quando o dente é reimplantado em até 30 minutos conservado em meio líquido adequado. As pesquisas têm demonstrado que o sucesso do reimplante 
está relacionado diretamente com a manutenção da vitalidade do ligamento periodontal, e não com o tempo de permanência extra-alveolar, evidentemente num meio de conservação adequado. Esse posicionamento é coerente com a proposta de ANDREASEN et al. ${ }^{27}$, em que o meio de conservação propício é mais importante que o tempo de permanência extraalveolar para o sucesso do reimplante, pois a vitalidade do ligamento periodontal foi mantida. Entretanto, os profissionais continuam valorizando apenas o tratamento com base no fator tempo, o qual é extramamente valioso para o sucesso da reimplantação até 30 minutos após a avulsão conforme comentado anteriormente e, como essa situação nem sempre é possível, recomendam procedimentos arcaicos como a imersão dente avulsionado em água ou saliva ${ }^{93}$.

Esta realidade, sem dúvida, deve ser modificada e isso vem ocorrendo nos últimos tempos, o que pode ser verificado em nossos resultados (Tabela 3) em que 74 pacientes que tiveram seus dentes reimplantados, 17 (22,9 \%) trouxeram o dente avulsionado imerso em leite. Todavia KRASNER et al. $^{93}$, afirmaram que a imersão do dente avulsionado em água ou saliva é um procedimento ainda recomendado. Avaliando esta conduta encontramos o trabalho de WEINSTEIN; WORSAAE; ANDREASEN ${ }^{163}$, que comparando estes dois procedimentos em animais, verificaram melhor reparo periodontal e significativa diminuição dos níveis de reabsorção inflamatória, nos dentes que foram lavados em água corrente.

Não podemos descartar a necessidade, em muitas situações, do tratamento da superfície radicular na tentativa de se conseguir o sucesso da reimplantação. Um desses procedimentos é aumentar a dureza do cemento e nesse sentido SHULMAN; KALIS; GOLDHABER ${ }^{150}$ propuseram a utilização do fluoreto de sódio, substância que transforma a 
hidroxiapatita em fluorapatita que é mais resistente ao processo de reabsorção e $\operatorname{COCCIA}^{48}$, avaliando clinicamente dentes que foram reimplantados depois do tratamento com fluoreto de sódio a $2 \%$ encontrou uma redução significante dos níveis de reabsorção. Com o propósito também de aumentar a dureza do cemento BJORVATN et al. ${ }^{35}$. e SELVIG et al. ${ }^{149}$, utilizaram uma solução de fluoreto de estanho a $1 \%$.

Nesse sentido ANDREASEN ${ }^{23}$ recomenda que dentes com ligamento periodontal necrótico, sejam imersos durante 20 minutos em uma solução de fluoreto de sódio a 2,4\%. LINDSKOG et al. ${ }^{98}$, recomendam a remoção mecânica do ligamento periodontal necrótico, deixando a superfície radicular desnuda, enquanto que GORDON et al. ${ }^{67}$ preconizam a imersão do dente na solução de hipoclorito de sódio a 5\%, por 8 minutos, para essa mesma finalidade.

Há, ainda, sugestões para evitar ou minimizar a contaminação bacteriana, submergindo o dente previamente ao reimplante em soluções contendo antibiótico. CVEK et al. ${ }^{54}$ sugeriram uma suspensão de dicloxacilina ( $1 \mathrm{mg}$ dissolvido em $20 \mathrm{ml}$ de soro fisiológico) por 5 minutos. SAE-LIM; METZGER; TROPE ${ }^{141}$, recomendam a aplicação tópica de um antinflamatório, a dexametasona, na concentração de $16 \mu g$ por ml de Viaspan, objetivando prevenir a reabsorção inflamatória.

Em nossos achados não temos casuística com referência ao tratamento da superfície radicular considerando que consta nos prontuários, simplesmente o borrifo com água.

A literatura tem demonstrado que os variados tratamentos da superfície radicular de dentes avulsionados e reimplantados não têm proporcionado, a contento, o reparo do ligamento periodontal, isto 
é, a incidência do processo de reabsorção é grande, como se observa nos trabalhos clínicos e experimentais em animais, MORI ${ }^{113}$.

\subsection{5 - Tipo de contenção empregado}

A definição de contenção ou esplintagem dental foi introduzida pela AMERICAN ASSOCIATION OF ENDODONTICS em 1984, como sendo um dispositivo rígido ou flexível para suportar, proteger ou imobilizar dentes luxados, reimplantados, fraturados ou submetidos a procedimento cirúrgico de natureza endodôntica. Sua finalidade é estabilizar o dente durante o período que se fizer necessário, para permitir a regeneração da estrutura do periodonto de sustentação.

A contenção moderna deve ser aplicada no dente de uma maneira direta, sem exigir etapas laboratoriais, não traumatizando-o, mantendo sua posição original e assim permanecer posicionado por todo o período necessário. Estas contenções não podem causar danos ao tecido gengival e nem aumentar o risco de cáries, permitindo uma fácil higienização, ter boa aparência estética, não interferir na oclusão e possibilitar a aplicação dos testes de sensibilidade pulpar, assim como intervenção endodôntica durante o período de fixação. A posição do dente após a reimplantação, deve ser tal, que exerça pressão mínima entre a superfície radicular e osso alveolar, permitindo uma pequena mobilidade que auxilia a reorientação funcional das fibras do ligamento periodontal neoformado bem como sua remoção parcial para verificação da estabilidade do dente.

As técnicas de contenção que obedecem àqueles princípios, utilizam resina composta, resina associada a fio de aço flexível ou de nylon ${ }^{59,125,126}$. 
A ocorrência da anquilose é atribuída em parte, ao tipo de contenção empregada e ao seu período de utilização. ANDREASEN et al. ${ }^{7}$, em seu estudo experimental com macacos, concluiram que a redução da estimulação mastigatória contribuiu para o desenvolvimento da anquilose, e quando a contenção rígida é mantida por longos períodos, áreas extensas de anquilose ficam evidentes. Com relação ao tempo, ANDREASEN et al. $^{25}$, recomenda que se limite a 2 semanas a sua utilização, isso nos casos de avulsão, podendo este período se estender para até 6 semanas, diante da evidência de comprometimento do osso alveolar.

Nosso estudo encontrou 26 casos onde foi empregada a contenção com resina composta, em outros 23 foi usada a associação resina e fio de aço flexível, sendo que 3 casos não receberam nenhum tipo de contenção. Em 22 pacientes da amostra, não foi possível obter essa informação. Quanto ao período, foi utilizado em nossa amostra 14 dias, todavia não foi possível encontrar nos prontuários e na proservação dos casos mais recentes, dados clínicos e radiográficos como anquilose e reabsorção que pudessem estar relacionados ao tipo de contenção utilizada.

\subsection{6 - Medicação sistêmica}

Dos trabalhos que abordam a prescrição de medicação sistêmica, alguns são artigos de revisão, BARRET; $\mathrm{KENNY}^{30}$, BRAMANTE et al. $^{42}$, HAMMARSTRÖN et al. $^{74}$, KRASNER; RANKOW $^{93}$, SCOTT; ZELIKOW ${ }^{148}$ e, não sendo experimentais, limitamse a indicar antibioticoterapia nos reimplantes dentais, mas não especificam a droga nem o tempo de utilização, creditando a estes fármacos a capacidade de prevenir a proliferação bacteriana. TROPE ${ }^{158}$, em sua publicação propondo um protocolo de atendimento, indica a prescrição de penicilina V potássica, $500 \mathrm{mg}$ quatro vezes ao dia, durante o período em que o dente permanecer com a contenção, ou seja, de 7 a 10 dias. 
Assim também manifestaram-se ANDREASEN; HJÖRTING-HANSEN ${ }^{13}$ em trabalho retrospectivo de 110 dentes humanos reimplantados, onde 50 pacientes tomaram penicilina imediatamente após o reimplante e 60 não utilizaram nenhuma droga. Encontraram equilíbrio nos dois grupos, isto é, os índices de sucesso e insucesso foram semelhantes.

Por sua vez, os trabalhos experimentais em animais: CVEK et al. ${ }^{53}$, HAMMARSTRÖM et al. ${ }^{75}$, SAE-LIM; WANG; TROPE ${ }^{140}$, mostraram menor contaminação bacteriana nas polpas dos animais submetidos a antibioticoterapia, realizada com dicloxacilina ${ }^{53}$, streptocilina $^{75}$ e amoxicilina ${ }^{140}$.

O protocolo para reimplantação de dentes avulsionados do Serviço de Urgência Odontológica da Faculdade de Odontologia de Bauru-USP, preconiza a prescrição de ampicilina 250 mg, tomada de 8 em 8 horas durante 7 dias (dose infantil), quando o paciente não relata histórico de sensibilidade à penicilinas, caso contrário, a droga de escolha é o estolato de eritromicina ( Tabela 4 ).

SCOTT; ZELIKOW ${ }^{148}$ e ANDREASEN; HJÖRTINGHANSEN $^{13}$, assim como KEMP; GROSSMAN; PHILLIPS ${ }^{88}$, são de opinião que o paciente deve se reportar a um médico, sobre a necessidade de profilaxia para o tétano, quando o dente avulsionado tiver contatado com o solo, opinião que compartilhamos.

\subsection{7 - Proservação instituída}

No aspecto do tratamento de dentes reimplantados são muitas as controvérsias em relação aos procedimentos endodônticos. Nos primeiros estudos clínicos em humanos ${ }^{20,97}$ e experimentais em animais ${ }^{101}$, o tratamento endodôntico era realizado no dente fora do alvéolo (preparo biomecânico seguido de obturação com guta-percha e cimento). Posteriormente, o protocolo proposto pela A.A.E. ${ }^{4}$ não recomendava 
aquele tratamento de forma imediata, e que deveria ser adiado para um período posterior ao reimplante, objetivando diminuir o tempo de permanência extra-alveolar, a menos que o dente apresentasse rizogênese incompleta e armazenado seco por mais de 2 horas. O tempo e a natureza do tratamento endodôntico no dente reimplantado era planejado para inibir ou controlar a infecção, e assim prevenir a reabsorção radicular inflamatória.

O tratamento endodôntico para dentes reimplantados pode ser dividido em 3 estágios:

- Pulpectomia: embora seja consenso nos protocolos de tratamento $3,4,30,42,55,92,93,158$ que a polpa deva ser removida dentro de 7 a 14 dias, após o reimplante, nenhum trabalho tem se voltado especificamente para essa questão. Revisando a literatura, HAMMARSTRÖM et al. ${ }^{74}$ citaram um texto de ANDREASEN et al. ${ }^{25}$ que faz referência ao tempo adequado para a pulpectomia, de 7 a 14 dias. Mais recentemente GREGORIOU ; JEANSONNE; MUSSELMAN $^{68}$ confirmaram aquele período, citando 3 textos extraídos de livros e a recomendação da A.A.E. ${ }^{4}$, como exemplos. Estas referências estão baseadas no estudo de ANDREASEN ${ }^{16}$, que observou experimentalmente, em animais, a ocorrência da reabsorção inflamatória, quando a pulpectomia não era realizada dentro de 7 dias. Nosso estudo encontrou como tempo médio para execução da pulpectomia um período de 7 dias pós reimplantação, porém, os dentes reimplantados que apresentavam ápice incompleto e tempo de permanência extra-alveolar inferior a 2 horas, tiveram a pulpectomia adiada, na expectativa de uma revascularização. Em função desse procedimento, foi possível constatar a ocorrência de revascularização pulpar em 2 casos contidos na nossa amostra, representando 28,5\% dos dentes que apresentavam as características anteriormente descritas (7 
dentes). Acreditamos que o percentual de revascularização possa ser bem maior, isso porque os testes de sensibilidade pulpar e de cavidade são pobres para revelar a ocorrência ou não de revascularização pulpar, segundo MESAROS; TROPE ${ }^{112}$. A determinação correta da condição pulpar em dentes com ápice incompleto é fundamental, pois, na vigência da necrose pulpar e consequentemente inflamação do tecido periodontal, provoca uma perda rápida do tecido calcificado, considerando que os túbulos dentinários são amplos e a parede radicular é de pequena espessura, BAKLAND ${ }^{28}$.

O correto diagnóstico da condição pulpar é um fator crítico, BAKLAND ${ }^{28}$ acredita que devido à presença de túbulos dentinários amplos e a pequena espessura da parede radicular, predispõe dentes imaturos a uma rápida perda do tecido calcificado quando acometidos por reabsorção inflamatória, em conseqüência da necrose pulpar.

- Medicação intermediária no canal: sem dúvida nenhuma, esta etapa da proservação é o item onde se encontra uma grande controvérsia na literatura. Analisando os protocolos propostos pela A.A.E. entre 1983 e 1994, pudemos observar várias modificações com relação ao tempo de duração do tratamento com hidróxido de cálcio, que foi a medicação intracanal utilizada em $100 \%$ da nossa casuística. No protocolo de 1983, a A.A.E. recomendava a utilização do $\mathrm{Ca}(\mathrm{OH})_{2}$ (hidróxido de cálcio) por um período mínimo de 6 e máximo de 12 meses, sendo que em 1994 passou a advogar a obturação do canal radicular, após 7 dias com curativo de $\mathrm{Ca}(\mathrm{OH})_{2}$. TROPE et al. ${ }^{157}$ investigando em animais, a terapêutica com $\mathrm{Ca}(\mathrm{OH})_{2}$ por períodos que variaram de 7 dias a 8 semanas, não relatou diferença significante sobre o reparo do ligamento periodontal, pressupondo que os 2 regimes de tratamento intermediário 
são equivalentes, entretanto, eles são partidários da terapia por longos períodos (8 semanas) como sendo a mais indicada. Esta afirmação foi posteriormente confirmada, por TROPE et al. ${ }^{159}$, pois observaram uma estabilização da reabsorção radicular inflamatória, em cães, quando utilizavam o $\mathrm{Ca}(\mathrm{OH})_{2}$ por longos períodos. Em contraste a esses resultados, DUMSHA; HOVLAND ${ }^{58}$, relataram não existir diferença entre dentes tratados com $\mathrm{CaOH}_{2}$ durante 7 meses e aqueles obturados com guta percha 14 dias após a reimplantação.

É interessante notar que, os estudos que avaliam o tempo de utilização do $\mathrm{Ca}(\mathrm{OH})_{2}$ como medicação intermediária, são realizados experimentalmente em animais e, consideram como "longo período" intervalos de tempo que variam de 2 semanas a 8 meses $^{58,68,76,95,96,159}$, o que nos leva a pactuar com VAN HASSEL et al. ${ }^{162}$ que consideraram as pesquisas realizadas com animais insuficientes para relacioná-las com o comportamento clínico de dentes reimplantados em humanos, pois, são realizadas com uma amostra muito pequena e períodos de avaliação inadequados.

Nos casos analisados em nosso levantamento foi adotada a terapêutica endodôntica com $\mathrm{Ca}(\mathrm{OH})_{2}$ por longo período, 1 a 2 anos (Tabela 5), conduta que se mostrou adequada para prevenir a reabsorção radicular inflamatória e talvez atenuar o processo de reabsorção por substituição, seqüelas freqüentes nos casos de reimplantação (Figura 10 ), porém, este regime de tratamento requer cooperação do paciente, tornando-se crítica a não observância das freqüentes trocas do medicamento, que pode levar a uma infecção, resultando em possível perda prematura do dente ${ }^{157}$ e frustração profissional $^{34,57}$. 


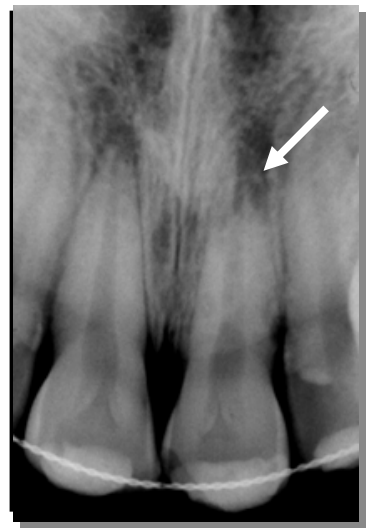

A

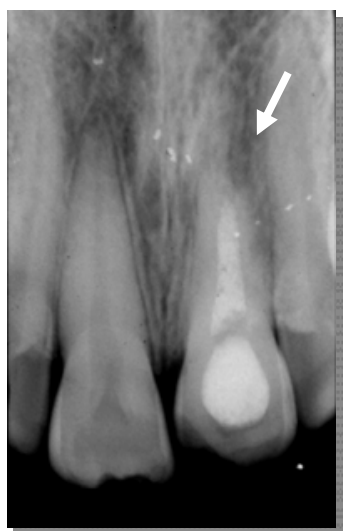

B

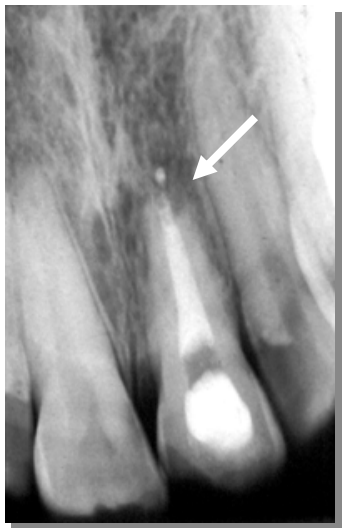

C

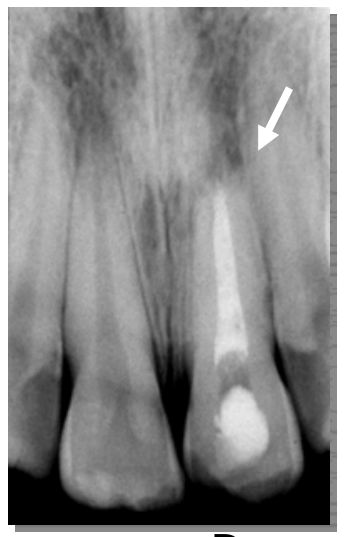

D

Figura 10 - Terapêutica endodôntica com $\mathrm{Ca}(\mathrm{OH})_{2}$ por longo período: A - inicial; B - 3 meses; C - 1 ano; D - 2 anos (reabsorção apical estabilizada - setas)

- Obturação do canal radicular: a obturação do canal radicular com guta percha e cimento, põe fim ao tratamento endodôntico do dente reimplantando, mas não à proservação que deverá ser realizada periodicamente. Como o objetivo do tratamento endodôntico de dentes avulsionados é minimizar os danos no ligamento periodontal, a obturação do canal radicular prévia ao reimplante, não é mais recomendada, a A.A.E. ${ }^{4}$ recomenda que se faça esse tratamento com o dente já posicionado no seu alvéolo.

\subsection{8 - Dados epidemiológicos}

A literatura, nos poucos trabalhos dessa natureza, revela uma incidência da avulsão dental variando de 0,5 \% a 3,0 \% dentre os casos de lesão traumática em dentes anteriores permanentes, e porisso é considerada uma injúria rara $^{103}$. MACKIE; WORTHINGTON ${ }^{102}$, observaram no seu levantamento realizado num período de 8 anos, uma incidência de 0,5 \%, enquanto SCHATZ; JOHO ${ }^{143}$ obtiveram um índice de 
0,7\% na análise retrospectiva de 7 anos. OIKARINEN; KASSILA ${ }^{122}$ obtiveram 2,0 \% revendo os atendimentos realizados pelo período de 2 anos.

Para obtermos um índice comparativo ao existente na literatura, nos baseamos em FERREIRA JR. ${ }^{62}$, que na sua dissertação de mestrado realizou um levantamento dos atendimentos feitos no Serviço de Urgência Odontológica da Faculdade de Odontologia de Bauru-USP, durante o período compreendido entre 1987 e 1995, verificando 1421 casos de traumatismo dental, em nosso levantamento encontramos 48 casos de avulsão no mesmo período, o que significa dizer, 3,47 \% de incidência ( Tabela 9 ).

Este estudo que envolveu 87 pacientes, num total de 116 dentes avulsionados, mostra na Figura 2 que os dentes mais atingidos são os incisivos centrais superiores, $72,4 \%$ e os laterais superiores, $17,2 \%$, o grupo restante, 10,4\% corresponde aos demais dentes que compõem a bateria anterior. Esses percentuais são bem próximos dos achados de ANDERSSON;BODIN ${ }^{9}$, onde $81,0 \%$ dos seus casos eram incisivos superiores, ANDREASEN; HJORTING-HANSEN ${ }^{13}$ encontraram os percentuais de $80,9 \%$ para os incisivos centrais e $12,7 \%$ para os laterais, ambos da maxila. Resultado semelhante foi encontrado por COCCIA ${ }^{48}$, ou seja, 70,5\% para incisivos centrais superiores e 20,9\% para os laterais superiores; LENSTRUP-SKIELLER ${ }^{97}$ contabilizaram 78,3\% e 15,0\% para os incisivos superiores, centrais e laterais respectivamente. O estudo retrospectivo de MACKIE; WORTINGHTON ${ }^{102}$ refere-se apenas ao percentual de 60,9\% para incisivos, sem diferenciá-los entre centrais e laterais. Bastante diferente dos demais é o resultado obtido por HEIMDAHL; VON KONOW; LUNDQUIST ${ }^{68}$ que afirmaram ser de 38,9\% a ocorrência de avulsão nos incisivos centrais superiores e 33,4\% nos laterais. O único relato de avulsão ocorrida em dentes posteriores 
pertence à GONDA et al. ${ }^{66}$, cuja amostra inclui um primeiro pré-molar inferior.

A falta de padronização nos dados epidemiológicos é uma constante, muitos dados são equivocados como por exemplo GONDA et al. $^{66}$, que define como sendo 16 anos a idade média de sua casuística, obtida pela aplicação pura e simples de média aritmética. Outras publicações limitaram-se a informar somente a faixa etária de 7 a 29 anos $^{9}$, 6 a $14^{102}, 9$ a $14^{48}, 6$ a $9^{51}$ e 3 a $13^{142}$. Na tabela 6, onde temos a distribuição por idade, observamos 47 casos na faixa etária compreendida entre 7 e 12 anos, o que corresponde a 45\% da nossa amostra, resultado bem próximo as de ANDREASEN; HJORTING-HANSEN ${ }^{13}$ e LENSTRUP; SKIELLER ${ }^{97}, 64,6 \%$ e 60,8\% respectivamente, para a mesma faixa etária, isto é, de 7 a 12 anos.

No que se refere à incidência por sexo, os trabalhos são unânimes em apontar uma maior incidência no sexo masculino. Nossa casuística não foi diferente, encontrou $60,9 \%$ para o sexo masculino e 39,1\% para o feminino. Para uma análise comparativa, a Tabela 12 abaixo, resume os resultados encontrados na literatura.

Tabela 12 - Autores e incidência por sexo

\begin{tabular}{|c|c|c|}
\hline AUTORES & MASC. & FEMIN. \\
\hline ANDERSON; BODIN ${ }^{9}$ & $50,8 \%$ & $49,2 \%$ \\
\hline ANDREASEN; HJORTING-HANSEN ${ }^{13}$ & $67,0 \%$ & $33,0 \%$ \\
\hline GROSSMAN; SHIP ${ }^{71}$ & $70,4 \%$ & $29,6 \%$ \\
\hline HEIMDAHL; VON KONOW; LUNDQUIST ${ }^{78}$ & $72,7 \%$ & $27,3 \%$ \\
\hline LENSTRUP; SKIELLER $^{97}$ & $68,4 \%$ & $31,6 \%$ \\
\hline MACKIE; WORTHINGTON ${ }^{103}$ & $69,3 \%$ & $30,7 \%$ \\
\hline OIKARINEN; KASSILLA ${ }^{122}$ & $73,0 \%$ & $27,0 \%$ \\
\hline SCHATAZ; HAUSHERR; JOHO ${ }^{144}$ & $66,0 \%$ & $34,0 \%$ \\
\hline
\end{tabular}

A explicação para estes resultados parece estar relacionada às características inerentes ao sexo masculino, que está sempre mais envolvido com brincadeiras e práticas esportivas coletivas, sendo portanto, mais suscetíveis ao traumatismo ${ }^{51}$. 
Ainda foi possível observar que a grande maioria dos acidentados pertencem à raça branca, 81,6 \%, seguidos dos negros, 17,2\% e, amarelos com 1,2 \% de incidência (Figura 4).

As causas e tipos de acidentes que levam ao traumatismo variam de acordo com a origem do material utilizado no levantamento. Os poucos estudos clínicos retrospectivos que analisaram este aspecto, importantíssimo para implementação de medidas preventivas, revelam etiologias diferentes dependendo de onde os dados foram coletados, se em hospital, clínicas de universidades ou do serviço odontológico público $^{122}$.

Como causa mais freqüente da avulsão dental, encontramos vários tipos de quedas acidentais, sendo 25 casos, seguida pelos acidentes com bicicletas onde tivemos 11 ocorrências e em menor número verificamos vítimas de agressão física, atropelamentos e acidentes automobilísticos. Todos estes dados estão expressos na Tabela 7. CRONALARSSON; NORÉN ${ }^{51}$, estudando os tipos de acidentes que levaram 1961 pacientes a buscar atendimento na Faculdade de Odontologia de Gothenburg, Suécia, observaram prevalência semelhante à da nossa amostra. Com base nos dados coletados na literatura ${ }^{51,66,71,88}$, pudemos no nosso levantamento, inferir que as causas da avulsão em ordem decrescente de ocorrência são: quedas acidentais, prática esportiva, bicicleta, agressão física e acidentes automobilísticos. Dentre estas situações, é possível dizer que, acidentes durante a prática de esportes e a utilização de bicicletas, são situações onde o traumatismo é previsível, devendo ser adotadas medidas preventivas como por exemplo a utilização de protetores bucais ${ }^{123}$.

Na revisão da literatura não encontramos referência ao ambiente em que ocorrem estes acidentes, esta informação, a nosso ver, é importante para direcionar campanhas de orientação sobre condutas frente 
os casos de avulsão. Em nosso levantamento constatamos que os acidentes ocorreram com maior freqüência no ambiente residencial e em segundo lugar, durante a permanência na escola (Tabela 8). E nesses locais, a propósito, residências e escolas encontra-se com facilidade o leite, meio adequado para armazenamento de dente avulsionado, bastando para isso que se leve esta informação aos indivíduos que estão ali presentes.

A Tabela 9, que contém a distribuição dos acidentes no período analisado (1983 a 2000) por este estudo, mostra um aumento na incidência dos casos de avulsão a partir do ano de 1990 o que, à primeira vista, é um dado conflitante, pois era de se esperar uma diminuição destas ocorrências pela disseminação das informações sobre a possibilidade de acidentes com avulsão dental, pelos motivos já discutidos. Porém, o referido ano foi marcado por um plano econômico, onde ocorreu o congelamento de preços, gerando uma euforia no consumo permitindo que uma maior parcela da população tivesse acesso a bens, como por exemplo: uma bicicleta.

Consultando os trabalhos de CRONA-LARSSON; NORÉN ${ }^{51}$, OIKARINEN; KASSILA ${ }^{122}$ e SCHATZ; JOHO ${ }^{144}$, constatamos que a época do ano de maior incidência do trauma dental é a primavera e o verão. Nossos resultados (Figura 6) apontam uma maior incidência durante o outono, que em nosso país esta dentro do período escolar.

O número de dentes avulsionados por paciente é determinado por 4 fatores, energia e direção do impacto, resiliência e forma do objeto agressor, que podem levar a 3 categorias de injúrias baseadas na sua severidade: branda, moderada e intensa, nesta última incluem-se as avulsões ${ }^{123}$. 
O mecanismo da injúria é determinado em termos pela forma e resiliência do objeto e também pela superfície que o dente tenha tocado. Como superfície resiliente inclui-se a terra ou alguma outra substância correspondente (areia, água, barro, etc.) e superfície dura o gelo, o fundo e as paredes laterais da piscina, assim como qualquer tipo de pavimentação. Para exemplificar objetos resilientes podemos citar a mão fechada, cotovelo, cabeça, ou qualquer outro objeto não rígido que possa atingir diretamente a arcada dental. Como objetos rígidos temos bastões de madeira (utilizados em algumas práticas esportivas) e garrafas. Dentro destes aspectos ainda podemos considerar a proteção oferecida pelo lábio $^{123}$.

Conhecidas estas informações podemos nos reportar à Figura 5, que mostra o número de dentes afetados por paciente, onde 78,1\% tiveram 1 dente avulsionado, 13,8\% com 2 avulsões, sendo menos freqüente os casos com 3 e 4 dentes avulsionados, nestes casos, os percentuais encontrados foram de 4,6\% e 3,5\%, respectivamente. Nosso estudo não teve condições de relacionar diretamente a quantidade de dentes avulsionados por paciente, com o mecanismo da injúria que causou a avulsão. Os trabalhos constantes da Tabela 13 citaram apenas os percentuais de dentes avulsionados por paciente, mas não relacionaram as causas.

Tabela 13 - Autores, número e percentual de dentes avulsionados por paciente

\begin{tabular}{l|r|r|c|c}
\hline \multirow{2}{*}{\multicolumn{1}{c|}{ AUTORES }} & \multicolumn{5}{c}{ N$^{\circ}$. DE DENTES AVULSIONADOS } \\
& \multicolumn{1}{c|}{$\mathbf{1}$} & $\mathbf{2}$ & $\mathbf{3}$ & $\mathbf{4}$ \\
\hline \hline ANDERSON; BODIN $^{9}$ & 83,3 & 16,7 & - & - \\
\hline GROSSMAN; SHIP $^{71}$ & 85,2 & 13,0 & - & - \\
\hline HEIMDAHL; VON KONOW; LUNDQUIS $^{78}$ & 72,7 & 9,1 & - & - \\
\hline KEMP; GROSSMAN $^{88}$ & 80,0 & 20,0 & - & - \\
\hline LENSTRUP; SKIELLER $^{97}$ & 76,1 & 17,4 & 6,5 & - \\
\hline
\end{tabular}


O prognóstico da reimplantação não pode ser garantido devido à complexidade dos fatores que interferem neste tipo de procedimento, amplamente abordados nesta discussão. Dentes reimplantados em condições ideais podem fracassar, enquanto outros considerados desfavoráveis podem resultar em sucesso, esta situação fica bem demostrada no relato clínico de CASTERLINE ${ }^{47}$, onde uma paciente de 31 anos de idade com doença periodontal avançada, teve o dente 11 avulsionado e reimplantado 1 hora após a avulsão. Depois de 2 anos o dente ainda estava presente na cavidade bucal e em função.

Na nossa casuística encontramos 1 caso onde uma paciente com 6 anos de idade, na época da avulsão, teve o dente 21 reimplantado pelo cirurgião-dentista da escola, mas não recebeu o tratamento inicial adequado, isto é, não foi empregado nenhum tipo de contenção assim como não foi instituída a proservação. Durante a avaliação clínica, 3 anos após a reimplantação, era possível observar um discreto escurecimento da coroa dental e nenhuma alteração nos níveis de mobilidade do dente. O exame radiográfico mostrou a interrupção do desenvolvimento radicular em virtude da necrose pulpar. Foi instituída a terapêutica endodôntica com $\mathrm{CaOH}_{2}$, estando o dente funcional por mais de 4 anos (Figura 11). 


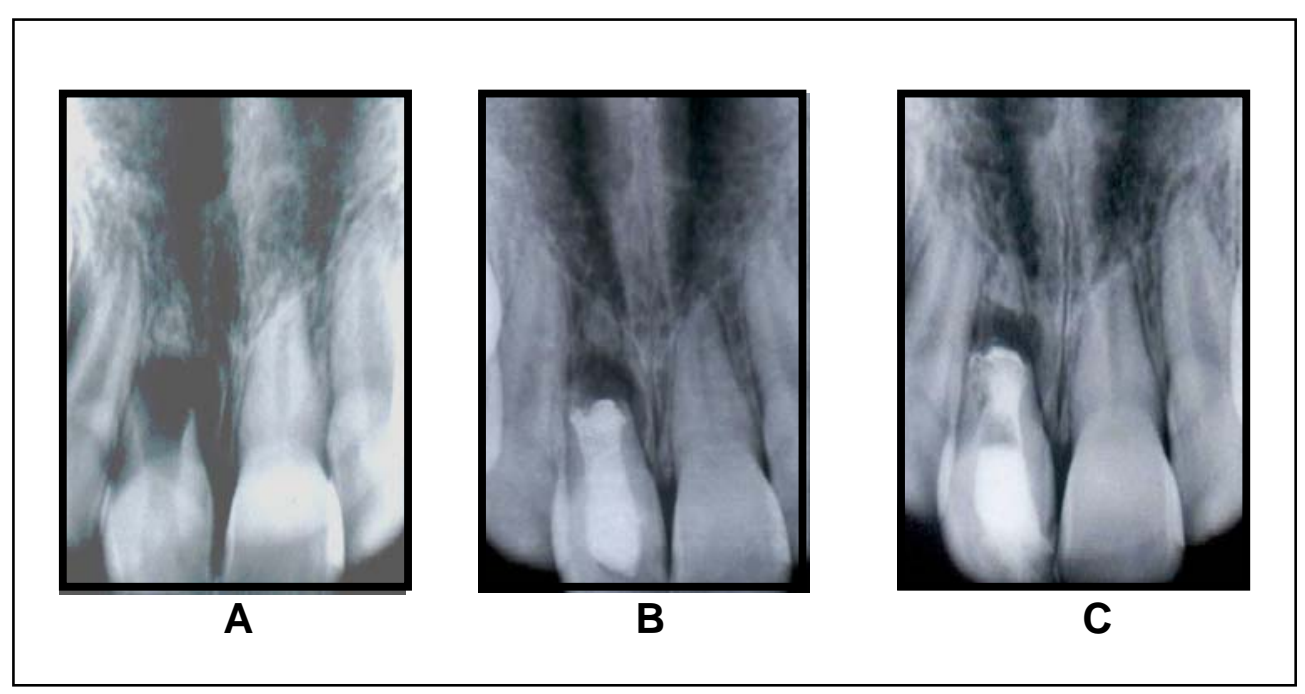

Figura 11 - Intervenção endodôntica tardia: A - 3 anos após a reimplantação; B - curativo intra canal com $\mathrm{Ca}(\mathrm{OH})_{2}$; C -6 anos após o reimplante

O reimplante deve ser realizado por mais pobre que seja o prognóstico. Deve ser considerado que na criança o dente deve ser mantido em seu alvéolo, se possível, durante todo o período de desenvolvimento facial. No caso do adulto a situação é semelhante, pois o alvéolo desprovido, repentinamente, da raiz dental desenvolverá um processo de reparo anatomicamente deficiente para um implante osseointegrado.

As informações sobre os procedimentos frente à avulsão dental devem ser melhor difundidas aos professores, centros de saúde, creches, clubes e cirurgiões-dentistas para melhorar o prognóstico dos dentes avulsionados e reimplantados, pois foi possível perceber nesse levantamento que o conhecimento do público leigo evoluiu em relação à conservação dos dentes avulsionados. Entre os profissionais da Odontologia persiste ainda o conceito do reimplante imediato, independente do tempo de permanência extra-alveolar e do meio de conservação utilizado. 


\section{7 - CONCLUSÕES}




\section{7 - CONCLUSÕES}

Os dados obtidos nos prontuários do Serviço de Urgência Odontológica da Faculdade de Odontologia de Bauru da Universidade de São Paulo, no período de janeiro de 1983 a dezembro de 2000 permitem concluir, confrontando-os com a literatura pertinente, o seguinte:

1. Que nos últimos 5 anos o grau de conhecimento do público leigo em relação à conservação dos dentes avulsionados melhorou muito;

2. Perdura, ainda, entre os profissionais da Odontologia o conceito do reimplante imediato, independente do tempo de permanência extra-alveolar e do meio de conservação utilizado;

3. A terapêutica endodôntica realizada com curativo intra-canal de $\mathrm{CaOH}_{2}$, pelo período de 1 a 2 anos, mostrou-se eficiente na prevenção da reabsorção inflamatória;

4. A maior incidência foi na faixa etária de 8 a 12 anos.

5. Os demais dados epidemiológicos são compatíveis com aqueles da literatura especializada. 


\section{REFERÊNCIAS BIBLIOGRÁFICAS}




\section{REFERÊNCIAS BIBLIOGRÁFICAS}

1. ABRAMS, R. Tooth replantation: 11-year follow-up. Aust. Dent. J., v.32, n.6, p. 427-9, Dec. 1987.

2. ALEO, J.J.; DE RENZIS, F.A.; FARBER, P.A. In vitro attachment of human gingival fibroblasts to root surfaces. J. Periodont., v.46, n.11, p. 639-45, Nov. 1975.

3. ALVES, D.F. Filosofia do reimplante dentário. Odontol. Mod., v.24, n.5, p.24-5, jan./fev. 1997.

4. AMERICAN ASSOCIATION OF ENDODONTISTS. Treatment of the avulsed permanent tooth. Recommended guidelines of the A.A.E. Dent. Clin. N. Amer., v.39, n.1, p.221-5, Jan. 1995.

5. ANDERSON, A.W.; SHARAV, Y.; MASSLER, M. Periodontal reattachment after tooth replantation. Periodontics, v.6, n.4, p.1617, Aug. 1968.

6. ANDERSSON, L. et al. Tooth ankylosis . Clinical, radiographic and histological assesment. Int. J. oral Surg., v.13, n.5, p.423-31, 1984.

7. ANDERSSON, L. et al. Effect of masticatory stimulation on dentoalveolar ankylosis after experimental tooth replantation. Endod. Dent. Traumat., v.1, n.1, p.13-6, Feb. 1985.

8. ANDERSSON, L.; BODIN, I.; SÖRENSEN, S. Progression of root resorption following replantation of human teeth after extended extraoral storage. Endod. Dent. Traumat., v.5, n.1, p.38-47, Feb. 1989.

* Normas recomendadas para uso no âmbito da Universidade de São Paulo, com base no documento "Referências Bibliográficas: exemplos", emanado do Conselho Superior do Sistema Integrado de Biblioteca da USP, em reunião de 20 de setembro de 1990. 
9. ANDERSSON, L.; BODIN, I. Avulsed human teeth replanted within 15 minutes - a long-term clinical follow-up study.

Endod. Dent. Traumat.,v. 6, n.1, 37-42, Feb. 1990.

10. ANDREASEN, F.M.; ANDREASEN, J.O. Diagnosis of luxation injuries: the importance of standardized clinical radiographic and photographic techniques in clinical investigations. Endod. dent. Traumat., v. 1, n.5, p.160-9, June 1985.

11.ANDREASEN, F.M. Transient apical breakdown and its relation to color and sensibility changes after luxation injuries to teeth. Endod. dent. Traumat., v. 2, n.2, p. 9-19, Feb. 1986.

12.ANDREASEN, F.M. et al. Radiographic assessment of simulated root resorption cavities. Endod. dent. Traumat., v. 3, n. 1, p. 217, Feb. 1987.

13. ANDREASEN, J.O.; HJÖRTING-HANSEN, E. Replantation of teeth. I-Radiographic and clinical study of 110 human teeth replanted after accidental loss. Acta odont. scand., v.24, n.3, p.263-86, Nov. 1966.

14. ANDREASEN, J.O.; HJÖRTING-HANSEN, E. Replantation of teeth. II-Histological study of 22 replanted anterior teeth in humans. Acta odont. scand., v.24, n.3, p.287, Nov. 1966.

15. ANDREASEN, J.O. The effect of splinting upon periodontal healing after replantation of permanent incisors in monkeys. Acta odont. scand., v.33. n.6, p.313-23, 1975.

16. ANDREASEN, J.O. Periodontal healing after replantation of traumatically avulsed human teeth. Assesment by mobility testing and radiography. Acta odont. scand., v.33, n.6, p.323-35, 1975.

17. ANDREASEN, J.O. et al. Periodontal and pulpal healing of monkey incisors in preserved tissue culture before replantation. Int. J. oral Surg., v. 7, n.2, p.104-12, 1978.

18. ANDREASEN, J.O. The effect removal of the coagulum in the alveolus before replantation upon pulpal and periodontal healting of mature permanent incisors in monkeys. Int. J. oral Surg., v.9, n.6, p.458-61, 1980. 
19. ANDREASEN, J.O. Periodontal healing after replantation and autotransplantation of permanent incisors. Int. J. oral Surg., v.10, n.1, p.54-61, 1981.

20. ANDREASEN, J.O.; KRISTERSON, L. The effect of extraalveolar root filling with calcium hydroxide on periodontal healing after replantation of permanent incisors in monkeys. J. Endod., v.7, n.8, p.349-54, Aug. 1981.

21. ANDREASEN, J.O.; KRISTERSON, L. The effect of limited drying or removal of the periodontal ligament. Periodontal healing after replantation of mature permanent incisors in monkeys. Acta odont. scand., v.39, n.1, p.1-13, 1981.

22. ANDREASEN, J.O.; SCHWARTZ, O. The effect of saline storage before replantation repair dry damage if the periodontal ligament. Endod. dent. Traumat., v.2, n.2, Apr. 1986.

23. ANDREASEN, J.O. Atlas of replantation and transplantation of teeth. Philadelphia, P.A., U.S.A.: W.B. Sanders Company, p. 823, 1992.

24. ANDREASEN, J.O. et al. Replantation of 400 avulsed permanent incisors. 1-Diagnosis of healing complications. Endod. dent. Traumat., v.11, n.2, p.51-8, Apr. 1995.

25. ANDREASEN, J.O. et al. Replantation of 400 avulsed permanent incisors. 2-Factors related to pulpal healing. Endod. dent. Traumat., v.11, n.2, p.59-68, Apr. 1995.

26. ANDREASEN, J.O.; BORUM, M.K.; ANDREASEN, F.M. Replantation of 400 avulsed permanent incisors. 3-Factors related to root growth. Endod. dent. Traumat., v.11, n.2, p.6975, Apr. 1995.

27. ANDREASEN, J.O. et al. Replantation of 400 avulsed permanent incisors. 4-Factors related to periodontal ligament healing. Endod. dent. Traumat., v.11, n.2, p. 76-89, Apr. 1995.

28. BAKLAND, L.K. Root resorption. Dent. Clin. N. Amer., v. 36, n. 3, p. 491-507, May 1992. 
29. BAKLAND, L.K.; ANDREASEN, J.O. Examination of the dentally traumatized patient. J. Calif. Dent. Ass., v.24, n.2, p.35-44, Feb. 1996.

30.BARRET, E.J.; KENNY, D.J. Avulsed permanent teeth: a review of the literature and treatment guidelines. Endod. dent. Traumat., v.13, n.4, p.153-63, Aug. 1997.

31. BARRET, E.J.; KENNY, D.J. Survival of avulsed permanent maxillary incisors in children following delayed replantation. Endod. dent. Traumat., v.13, n.6, p.269-75, Dec. 1997.

32. BARRY, G.N. Replanted teeth still functioning after 42 years: report a case. J. Amer. dent. Ass., v.92, p.412-3, Feb. 1976.

33. BATES, S. Absorption. Brit. J. dent. Sci., v.1, p.256, 1856 apud HENRY, J.L.; WEINMAN, J.P. ${ }^{76}$, p.270, 1951.

34. BHAMBHANI, S. Treatment and prognosis of avulsed teeth: a discussion and case report. Oral Surg., v.75, n.2, p.233-8, Feb. 1993.

35. BJORVATN, K.; SELVIG, K.A.; KLINGE, B. Effect of tetracycline and $\mathrm{SnF}_{2}$ on root resorption in replanted incisors in dogs. Scand. $\boldsymbol{J}$. dent. Res., v. 97, n. 1, p. 477-82, Feb. 1989.

36. BLOMLÖF, L.;OTTESKOG, P. Viability of human periodontal ligament cells after storage in milk or saliva. Scand. J. dent. Res., v.88, n.5, p.436-40, 1980.

37. BLOMLÖF, L. et al. Viability of periodontal ligament cells after storage in milk or saliva. Scand. J. dent. Res., v.88, n.5, p.441-5, 1980 .

38. BLOMLÖF, L. et al. Periodontal healing of replanted monkey teeth prevented from drying. Acta odont. scand., v.41, n.2, p.117-23, 1983.

39. BLOMLÖF, L. et al. Storage of experimentally avulsed teeth in milk prior to replantation. J. dent. Res., v.62, n.8, p.912-6, Aug. 1983. 
40. BLOMLÖF, L.; LINDSKOG, S. Quality of periodontal healing . II: dynamics of reparative cementum formation. Swed dent. J., v.18, n.4, p.131-8, July/Aug. 1994.

41. BODECKER, C.F.; LEFKOWITZ, W. Replantation of teeth. Dent. Items of Interest, v. 57, p.675-92, 1935.

42. BRAMANTE, C.M. Condutas clínicas na reimplantação dental. Rev. Ass. paul. cirurg. Dent., v.40, n.1, p.107-8, jan./fev. 1986.

43. BUTCHER, E.O.; VIDAIR, R.V. Periodontal fiber reattachment in replanted incisors of teeth monkey. J. dent. Res., v.34, n.4, p.56976, Aug. 1955.

44. ÇALISKAN, M.K.; TÜRKÜN, M. Clinical investigation of traumatic injuries of permanent incisors in Izmir, Turkey. Endod. dent. Traumat., v.11, n.5, p.210-13, Oct. 1995.

45. ÇALISKAN, M.K.; TÜRKÜN, M.; GÖKAY, N. Delayed replantation of avulsed mature teeth with calcium hydroxide treatment. $\boldsymbol{J}$. Endod., v.26, n.8, p.472-6, Aug. 2000.

46. CAMP, J.H. Recommended guidelines for tretatment of the avulsed tooth. J. Endod., v.9, n.8, p.571, Aug. 1983.

47. CASTERLINE, A.C. Replantation of avulsed central incisor with advanced periodontal disease: a case report. Endod. dent. Traumat., v.15, n.3, p.135-7, June 1999.

48. COCCIA, C.T. A clinical investigation of root resorption rates in reimplantation young permanent incisors. A five-year study. $\boldsymbol{J}$. Endod., v.6, n.1, Jan. 1980.

49. COMFORT, M.B. The prevention of contamination of teeth stored for transplantation. Oral Surg., v.49, n.3, p.200-1, Mar. 1980.

50. COSTICH, E.R. et al. Replantation of molar teeth in the syrian hamster. J. dent. Res., v.37, n.1, p.36-7, Feb. 1958.

51. CRONA-LARSSON, G.; NOREN, J.G. Luxation injuries to permanent teeth - a retrospective study of etiological factors. Endod. dent. Traumat., v.5, n.4, p.176-9, Aug. 1989. 
52. CVEK, M.; GRANATH, L.E.; HOLLENDER, L. Treatment of nonvital permanent incisors with calcium hydroxide. III-Variation of occurrence of replanted teeth with duration of extraalveolar period and storage environment. Odont. Revy, v.1, n.25, p.43-56, 1974.

53. CVEK, M. et al. Pulp revascularization in reimplanted immature monkey incisors - predictability and the effect of antibiotic systemic prophylaxis. Endod. dent. Traumat., v.6, n.4, p.157-69, Aug. 1990.

54. CVEK, M. et al. Effect of topical application of doxycycline in pulp revascularization and periodontal healing in re-implanted monkeys incisors. Endod. dent. Traumat., v.6, n.4, p.170-6, Aug. 1990.

55. DAVIS, M.J. Orofacial trauma management: patient assessment and documentation. N.Y. St. Dent. J., v.61, n.7, p.42-6, Aug./Sept. 1995.

56. DAWOODBHOY, I. et al. Splinting of avulsed central incisors with orthodontic wires: a case report. Endod. dent. Traumat., v.10, n.3, p.149-52, June 1994.

57. DUGGAL, M.S. et al. Replantation of avulsed permanent teeth with avital periodontal ligaments: a case report. Endod. dent. Traumat., v.10, n.6, p.282-5, Dec. 1994.

58. DUMSHA, T.; HOVLAND, E.J. Evaluation of long-term calcium hydroxide treatment in avulsed teeth - an in vivo study. Int. Endod. J., v.28, n.1, p.7-11, Jan. 1995.

59. EBELESEDER, K.A. et al. Splints made of wire and composite: na investigation of lateral tooth imobility in vivo. Endod. dent. Traumat., v.11, n.6, p.288-93, Dec. 1995.

60. EBELESEDER, K.A. et al. A study of replanted permanent teeth in different age groups. Endod. dent. Traumat., v.14, n.6, p.274-8, Dec. 1998.

61. FERLINI $\mathrm{F}^{\circ}$., J. Estudo radiográfico e microscópico das reabsorções radiculares na presença de periodontites apicais crônicas (microscopia óptica e eletrônica de varredura). Bauru, 1999. 186 p. Tese (Doutorado) - Faculdade de Odontologia de Bauru, Universidade de São Paulo. 
62. FERREIRA JR., O. Contribuição social do serviço de urgência odontológica da Faculdade de Odontologia de Bauru. Sua participação no convênio com o sistema único de saúde. Bauru, 1997. 116p. Dissertação (Mestrado) - Faculdade de Odontologia de Bauru, Universidade de São Paulo.

63. FLANAGAN, V.D.; MYERS, H.I. Delayed reimplantation of second molars in the syrian hamster. Oral Surg., v.11, n.10, p.1179-88, Oct. 1958.

64. FUSS, Z. Successful self-replantation of avulsed tooth with 42 year follow-up. Endod. dent. Traumat., v.1, n.3, p.120-2, June 1985.

65. GAYNOR, H.M. Replanting avulsed teeth via the acid-etch technic. Dent. Surv., v.52, n.2, p.58-62, Feb. 1976.

66. GONDA, F. et al. Replantation: an analysis of 29 teeth. Oral Surg., v.70, n.5, p.650-5, Nov. 1990.

67. GORDON, T.M.; DAMATO, D.; CHRISTNER, P. Solvent effect of various dilution of hipochlorit in vital and necrotic tissue. $\boldsymbol{J}$. Endod., v.7, n. 1, Jan. 1981.

68. GREGORIOU, A.; JEANSONNE, B.; MUSSELMAN, R. Timing of calcium hydroxide therapy in the treatment of root resorption in replanted teeth in dogs. Endod. dent. Traumat., v.10, n.6, p.268-75, Dec. 1994.

69. GREWE, J.M.; FELTS, W.J. Autoradiographic investigation of tritiated thymidine incorporation in to replanted and transplanted mouse mandibular incisors. J. dent. Res., v. 47, n.1, p.108-114, Jan./Feb. 1968.

70. GROPER, J.N.; BERNICK, S. Histological study of the periodontium following replantation of teeth in the dog. J. Periodont., v.37, p.2535, 1970.

71. GROSSMAN, L.I.; SHIP, I. Survival rate of replanted teeth. Oral Surg., v.29, n.6, p.899-906, 1970. 
72. HAMILTON, F.A.; HILL, F.J.; HOLLOWAY, P.J. An investigation of dento-alveolar trauma and is treatment in an adolescent population. Part 1: the prevalence and incidence of injuries and the extent and adequacy of treatment received. Brit. Dent. J., v.182, n.3, Feb. 1997.

73. HAMILTON, F.A.; HILL, F.J.; MACKIE, I.C. Investigation of lay knowledge of the management of avulsed permanent incisors. Endod. dent. Traumat., v.13, n.1, p.19-23, Feb. 1997.

74. HAMMARSTRÖM, L. et al. Tooth avulsion and replantation - a review. Endod. dent. Traumat., v.2, n.1, p.1-8, Feb. 1986.

75. HAMMARSTRÖM, L. et al. Replantation of teeth and antibiotic treatment. Endod. dent. Traumat., v.2, n.2, p.51-7, Apr. 1986.

76. HAMMARSTRÖM, L. et al. Effect of calcium hydroxide treatment on periodontal repair and root resorption. Endod. dent. Traumat., v.2, n.5, p.184-9, Oct. 1986.

77. HAMMARSTRÖM, L.; BLOMLÖF, L.; LINDSKOG, S. Dynamics of dento-alveolar ankylosis and associated root resorption. Endod. dent. Traumat., v.5, n.4, p.163-75, Aug. 1989.

78. HEIMDAHL, A.; von KONOW, L.; LUNDQUIST, G. Replantation of avulsed teeth after long extra-alveolar periods. Int. J. oral Surg., v.12, n.6, p.413-7, 1983.

79. HEISS, J., 1944 apud LÖE, H.; WAERHAUG, J. Experimental replantation of teeth in dogs and monkeys. Arch oral Biol., v. 3, n.3, p.176-84, 1961.

80. HENRY, J.L.; WEINMANN, J.P. The pattern of resorption and repair of human cementum. J. Amer. dent. Ass., v.42, n.3, p.270-90, Mar. 1951.

81. HILTZ, J.; TROPE, M. Vitality of human lip fibroblasts in milk, Hank's balanced salt solution and viaspan storage media. Endod. dent. Traumat., v.7, n.2, p.69-72, Apr. 1991.

82. HUNTER, J. apud YOUNGER, W.J. Transplantation of teeth into artificial sockets. Pacif. Med. Surg. J., v.29, p.17-27, 1886. 
83. INGÓLFSSON, A.R. et al. Efficacy of laser doppler flowmetry in determining pulp vitality of human teeth. Endod. dent. Traumat., v.10, n.2, p. 83-7, Apr. 1994.

84. JÄRVINEN, S.; OJALA, E. Replantation of young permanent incisors. A long term follow up study of seven cases with eleven replanted teeth. Acta odont. pediat., v.1, n.2, Dec. 1980.

85. JOHNSON, W.T.; JAMES, G.A. Replantation of avulsed teeth with immature root development. Oral Surg., v.60, n.4, p.420-7, Oct. 1985.

86. KAQUELER, J.C.; MASSLER, M. Healing following tooth replantation. J. Dent. Child., v.36, p.303-14, 1969.

87. KAWANAMI, M. et al. Infraposition of ankylosed permanent maxillary incisors after replantation related to age and sex. Endod. dent. Traumat., v.15, n.2, p.50-6, Apr. 1999.

88. KEMP, W.B.; GROSSMAN, L.I.; PHILIPS, J. Evaluation of 71 replanted teeth. J. Endod., v.3, n.1, 30-5, Jan. 1977.

89. KINIRONS, M.J.; BOYD, D.H.; GREGG, T.A. Inflammatory and replacement resorption in reimplanted permanent incisor teeth: a study of the characteristics of 84 teeth. Endod. dent. Traumat., v.15, n.6, p.269-72, Dec. 1999.

90. KLING, M.; CVEK, M.; MEJARE, I. Rate and predictability of pulp revascularization in therapeutically permanent incisors. Endod. dent. Traumat., v.2, n.3, p.83-9, June 1986.

91. KNIGHT, M.K.; GAMS, B.J.; CALANDRA, J.C. The effect of root canal therapy on replanted teeth of dogs. A gross roentgenographic and histologic study. Oral Surg., v.18, n.2, p.227-42, Aug. 1964.

92. KONIS, A.B. Treatment of a traumatic tooth avulsion. N.Y. St. dent. J., v.61, n.7, p.39-41, Aug./Sept. 1995.

93. KRASNER, P.; RANKOW, H.J. New philosophy for the treatment of avulsed teeth. Oral Surg., v.79, n.5, p.616-23, May 1995. 
94. KRISTERSON, L.; ANDREASEN J.O. Influence of root development on periodontal and pulpal healing after replantation of incisors in monkeys. Int. J. oral Surg., v.13, n.4, p.313-23, 1984.

95. LENGHEDEN, A.B.; BLOMLÖF, L.; LINDSKOG, S. Effect of immediate calcium hydroxide treatment and permanent root-filling on periodontal healing in contaminated replanted teeth. Scand. $\boldsymbol{J}$. dent. Res., v.99, n.2, p.139-46, Apr. 1991.

96. LENGHEDEN, A.B.; BLOMLÖF, L.; LINDSKOG, S. Effect of delayed calcium hydroxide treatment on periodontal healing in contaminated replanted teeth. Scand. J. dent. Res., v.99, n.2, p.14753, Apr. 1991.

97. LENSTRUP, K.; SKIELLER, V. A follow-up study of teeth replanted after accidental loss. Acta odont. scand., v.17, n.4, p.503-9, Dec. 1959.

98. LINDSKOG, S.; PIERCE, A.M.; BLOMLÖF, L. Chlorhexidine as a root canal medicament for treating inflammatory lesions in the periodontal space. Endod. dent. Traumat., v.14. n.4, p.186-90, Aug. 1998.

99. LINGHORNE, W.J.; O’CONNELL, D.C. Studies in the regeneration and reattachment of supporting structures of the teeth. I-Soft tissue reattachment. J. dent. Res., v.29, n.4, p.419-28, Aug. 1950.

100. LITWIN, J.; LUNDQUIST G.; SÖDER, P.O. Studies on the long-term maintenance of teeth and viable associated cells in vitro. Scand. $\boldsymbol{J}$. dent. Res., v.79, p. 536-9, 1971.

101. LÖE, H.; WAERHAUG, J. Experimental replantation of teeth in dogs and monkeys. Arch. Oral Biol., v.3, n.3, p.176-84, 1961.

102. MACKIE, I.C.; WORTHINGTON, H.V. An investigation of replantation of traumatically avulsed permanent incisor teeth. Brit. Dent. J., v.172, n.11, p.17-20, Jan. 1992.

103. MACKIE, I.C.; WORTHINGTON, H.V. An investigation of the children referred to a dental hospital with avulsed permanent incisor teeth. Endod. dent. Traumat., v.3, n.3, p.106-10, June 1993. 
104. MARINO, T.G.et al. Determination of periodontal cell viability in long sheff-life milke. J. Endod., v.26. n.12, p.699-702, Dec. 2000.

105. MARQUES, J.L.L.; CONTI, R.; ANTONIAZZI, J.H. Conduta clínica frente ao traumatismo dental. Rev. Ass. paul. cirurg. Dent., v. 48, n.6, p.1529-33, nov./dez. 1994.

106. MARQUES, J.L.L.; PROKOPOWITSCH, I.; ANTONIAZZI, J.H. Posicionador radiográfico personalizado para controle do tratamento endodôntico. Rev. Odont. USP, v.11, n.4, p.293-8, out./dez. 1997.

107. MASSLER, M. Tooth replantation. Dent. Clin. N. Amer., v.18, n.2, p.445-52, Apr. 1974.

108. MATSSON, L. ; ATTSTRÖM, R.; GRANATH, L. Ankylosis of experimentally reimplanted teeth related to extra-alveolar period and storage enviroment. Pediat. Dent., v.4, n.4, p.327-9, Dec. 1982.

109. MATSSON, L.; KLINGE, B.; HALLSTRÖM, H. Effect on periodontal healing of saline irrigation of the tooth socket before replantation. Endod. dent. Traumat., v.3, n.2, p.64-7, Apr. 1987.

110. MELCHER, A.H. On the repair potential of periodontal tissues. $\boldsymbol{J}$. Periodont., v.47, n.5, p.256-60, May 1976.

111. MENEZES, A.C.; MARÇAL, P.; ROCHA, E.S. Reimplantes de dentes avulsionados. Rev. Cent. Clin. Biom. U.F.U., v.1, n.1, p.59-61, dez. 1985.

112. MESAROS, S.V.; TROPE, M. Revascularization of traumatized teeth assessed by laser doppler flowmetry: case report. Endod. dent. Traumat., v.13, n.1, p.24-30, Feb. 1997.

113. MORI, G.G. Estudo microscópico do efeito do tratamento da superfície radicular com acetazolamida em dentes de ratos avulsionados e reimplantados. Bauru, 2002. 96 p. Dissertação (Mestrado) - Faculdade de Odontologia de Bauru, Universidade de São Paulo. 
114. MORRIS, M.L. et al. Factors affecting healing after experimentally delayed tooth transplantation. J. Endod., v.7, n.2, p.80-84, Feb. 1981.

115. NASJLETI, C.E. et al. Healing after tooth reimplantation in monkeys. A radio-autographic study. Oral Surg., v.39. n.3, p.361-75, Mar. 1975.

116. NASJLETI, C.E.; CASTELLI, W.A.; CAFFESSE, R.G. The effects of different splinting time on replantation of teeth in monkeys. Oral Surg., v.53, n.6, p.557-65, June 1982.

117. NE, R.F.; WITHERSPOON, D.E.; GUTMANN, J.L. Tooth resorption. Quintessence Int., v.30, n.1, p.9-25, Jan. 1999.

118. NEAVERTH, E.J.; GOERIG, A.C. Technique and rationale for splinting. J. Amer. dent. Ass., v.100, n.1, p.56-63, 1980.

119. NISHIOKA, M. et al. Tooth replantation in germ-free and conventional rats. Endod. dent. Traumat., v.14, n.4, p.163-73, Aug. 1998.

120. ÖHMAN, A. Healing and sensitivity to pain in young replanted human teeth. Odont. Trdskr., v.73, p.165-227, 1965.

121. OIKARINEN, K.; SEPPÄ, S.T. Effect of preservation media on proliferation and collagen biosynthesis of periodontal ligament fibroblasts. Endod. dent. Traumat., v.3, n.3, p.95-9, June 1987.

122. OIKARINEN, K.; KASSILLA, O. Causes and types of traumatic tooth injuries in a public health clinic. Endod. dent. Traumat., v.3, n.4, p.172-7,Aug. 1987.

123. OIKARINEN, K. Pathogenesis and mechanism of traumatic injuries to teeth. Endod. dent. Traumat., v.3, n.5, p.220-3, Oct. 1987.

124. OIKARINEN, K. Functional fixation for traumatically luxated teeth. Endod. dent. Traumat., v.3, n.5, p.224-8, Oct. 1987.

125. OIKARINEN, K. Tooth splinting: a review of the literature and consideration of the versatility of a wire-composite splint. Endod. dent. Traumat., v.6, n.6, p.237-50, Dec. 1990. 
126. OIKARINEN, K,; ANDREASEN, J.O.; ANDREASEN, F.M. Rigidity of various fixation methods used as dental splints. Endod. dent. Traumat., v.8, n.3, p.113-9, June 1992.

127. OIKARINEN, K. Dental tissues involved in exarticulation root resorption and factors influencing prognosis in relation to replanted teeth. Proc. Fin. dent. Soc., v.89, n.1-2, p.29-44, 1993.

128. OKAMOTO, T.; RAMALHO, A.C.; MARCANTONIO, E. Reimplante de incisivo superior de rato após obturação da cavidade pulpar. Rev. Fac. Odont. Araçatuba. V.4, n.1, p.137-45, 1975.

129. ÖSTBY, B.N. The role of the blood clot in endodontic therapy. An experimental histologic study. Acta odont. scand., v.19, n.3-4, p.323-53, Dec. 1959.

130. OSWALD , R.J.; HARRINGTON, G.W.; VAN HASSEL, H.J.Replantation. I-The role of the socket. J. Endod., v.6, n.3, p.479-84, Mar. 1980.

131. OSWALD, R.J.; HARRINGTON, G.W.; VAN HASSEL, H.J. A postreplantation evaluation and saliva stored avulsed teeth. J. Endod., v.6, n.5, p.546-51, May 1980.

132. PATIL, S.; DUMSHA, T.C.; SYDISKIS, R.F. Determining periodontal ligament (PDL) cell vitality from exarticulated teeth stored in saline or milk using fluorescein diacetate. Int. Endod. J., v.27, n.1, p.1-5, Jan. 1994.

133. PERTL, C. et al. Contemporary treatment of the resorbed avulsed tooth: a case report. Int. Endod. J., v.32, n.4, p.332-6, Aug. 1999.

134. PETTIETTE, M. et al. Periodontal healing of extracted dog's teeth airdried for extend periods and soaked in various media. Endod. dent. Traumat., v.13, n.5, p.113-8, Oct. 1997.

135. PETTINI, F.; PETTINI, P. Root resorption of replanted teeth: an SEM study. Endod. dent. Traumat., v.14, n.3, p.144-9, June 1998.

136. PIERCE, A.; HEITHERSAY, G.; LINDSKOG, S. Evidence for a direct inhibition of dentinoclasts by a corticosteroid antibiotic endodontic paste. Endod. dent. Traumat., v.4, n.1, p.44-5, Feb. 1988. 
137. RAPHAEL, S.L.; GREGORY, P.J. Parental awareness of the emergency management of avulsed teeth in children. Aust. Dent. J., v.35, n.2, p.130-3, Apr. 1990.

138. ROTHSCHILD, D.L.; GOODMAN, A.A.; BLAKEY, K.R. A histologic study of replanted and transplanted endodontically and nonendodontically treated teeth in dogs. Oral Surg., v.28, n.6, p.871-6, Dec. 1969.

139. SAE-LIM, V.; YUKEN, K.W. An evaluation of after-office-hour dental trauma in Singapure. Endod. dent. Traumat., v.13, n.4, p.164-70, Aug. 1997.

140. SAE-LIM , V.; WANG, C.Y.; TROPE, M. Effect of systemic tetracycline and amoxicilin on inflammatory root resorption of replanted dog's teeth. Endod. dent. Traumat., v.14, n.5, p.216-20, Oct. 1998.

141. SAE-LIM, V.; METZGER, Z.; TROPE, M. Local dexamethasone improves periodontal healing of replanted dog's teeth. Endod. dent. Traumat., v.14, n.5, p.232-6, Oct. 1998.

142. SANCHEZ, A.V.; GARCIA-GODOY, F. Traumatic dental injuries in 3-to 13-year-old boys in Monterrey, Mexico. Endod. dent. Traumat., v.6, n.2, p.63-5, Apr. 1990.

143. SCHATZ, J.P.; JOHO, J.P. A retrospective study of dentoalveolar injuries. Endod. dent. Traumat., v.10. n.1, p.11-4, Feb. 1994.

144. SCHATZ, J.P.; HAUSHERR, C. JOHO, J.P. A retrospective clinical and radiographic study of teeth re-implanted following traumatic avulsion. Endod. dent,. Traumat., v.11, n.5, p.235-9, Oct. 1995.

145. SCHATZ, J.P.; DUBREZ, B.; ROEHRICH, N. Muco-gingival and periodontal health recovery following reimplantation of teeth. Endod. dent. Traumat., v.15, n.5, p.216-20, Oct. 1999.

146. SCHEFF, J., 1890 apud LÖE, H; WAERHAUG, J. Experimental replantation of teeth in dogs and monkeys. Arch oral Biol., v.3, n. 3, p.176-84, 1961. 
147. SCHEIN, M.T.; ISOLAN, T.M.P. Esplint funcional de dentes traumatizados. Rev. Bras. Odont., v.54, n.4, p.225-7, jul./ago. 1997.

148. SCOTT, J.N.; ZELIKOW, R. Replantation - a clinical philosophy. $\boldsymbol{J}$. Amer. dent. Ass., v.101, n.1, p.17-9, July 1980.

149. SELVIG, K.A.; BJORVATN, K.; CLAFFEY, N. Effect of stannous fluoride and tetracycline on repair after delayed replantation of root-planed teeth in dogs. Acta odont. scand., v. 48, n. 4, p. 107-12, Oct. 1990.

150. SHULMAN, L.B.; KALIS, P.; GOLDHABER, P. Fluoride inhibition of tooth-replant root resorption in cebres monkeys. J. Oral Ther, v. 4, n. 5, p. 331-7, 1968.

151. SIDLEY, C.G. Endodontic management of the avulsed tooth and totth transplantation. Alpha Omegan, v.83, n.4, p.60-4, 1990.

152. SIERRA, J.G.; GUEVARA, R.G. Reabsorciones dentarias en dientes reimplantados por avulsion. Rev. Soc. Odont. Plata, v. 2, n.4, p.2933, nov. 1989.

153. SKOGLUND, A.; TRONSTAD, L. Pulpal changes in replanted and autotransplanted immature teeth of dogs. J. Endod., v.7, n.7, p.30916, July 1981.

154. SÖDER, P.Ö. et al. Effect of drying on viability of periodontal membrane. Scand. J. dent. Res., v.85, n.3, p.164-8, Mar. 1977.

155. TRONSTAD, L. Root resorption - etiology, terminology and clinical manisfestations. Endod. dent. Traumat., v.4, n.5, p.241-52, Oct. 1988.

156. TROPE, M.; FRIEDMAN, S. Periodontal healing of replanted dog teeth stored in Viaspan, milk, and Hank's balanced salt solution. Endod. dent. Traumat., v.8, n.3, p.183-8, June 1992.

157. TROPE, M. et al. Effect of different endodontic treatment protocols on periodontal repair and root resorption of replanted dog teeth. $\boldsymbol{J}$. Endod., v.18, n.10, p.492-6, Oct. 1992. 
158. TROPE, M. Clinical management of the avulsed tooth. Dent. Clin. $N$. Amer., v.39, n.1, p.93-112, Jan. 1995.

159. TROPE, M. et al. Short vs long-term calcium hydroxide treatment of established inflammatory root resorption in replanted dog teeth. Endod. dent. Traumat., v.11, n.3, p.124-8, June 1995.

160. TROPE, M. Protocol for treating the avulsed tooth. J. Calif. Dent. Ass., v.24, n.3, p.43-9, Mar. 1996.

161. TZIAFAS, D. Experimental bacterial anachoresis in dog dental pulps capped with calcium hydroxide. J. Endod., v.15, n.2, p.591-5, Dec. 1989.

162. VAN HASSEL, H.J.; OSWALD, R.G.; HARRINGTON, G.W. Replantation. 2-The role of the periodontal ligament. J. Endod., v.6, n.4, p.506-8, Apr. 1980.

163. WEINSTEIN, F.M.; WORSAAE, N.; ANDREASEN, J.O. The effect on periodontal and pulpal tissues various cleansing procedures prior to replantation of extracted teeth. An experimental study in monkeys. Acta odont. scand., v.39, n.4, p.251-5, Aug. 1981.

164. WILKINSON, F.C. Some observations of the replantation and transplantation of teeth, with special reference to the pathohistology of the tissues of attachment. Brit. Dent. J., v.38, p.92939, 1917.

165. WOEHRLE, R.R. Cementum regeneration in replanted teeth with different pulp treatment. J. dent. Res., v.55, n.2, p.235-8, Mar./Apr. 1976.

166. YOUNGER, W.J. Transplantation of teeth in to artificial sockets. Pacif. med. Surg., v.29, p.17-27, 1886. 
Abstract 105

ABSTRACT 


\section{ABSTRACT}

The objective os this project was to analyze the records of patients who suffered accidents and had avulsed and replanted teeth in the period between 1983 and 2000, attended to by the Dental Urgency Service of the School of Dentistry at Bauru of the University of São Paulo. Data regarding: the time of extra-alveolar permanence, the means used in the conservation of the avulsed tooth and the type of splint employed, as well as instituted preservation, correlating them to the current situation of the replanted dental element, was collected. This analysis was complemented by the following epidemiological data: the most affected dental, the age of the patients at the time of the replantation, gender, race, kind of accident, environment of the incident, the time of year with the highest incidence, and the number of avulsed teeth per patient. In such a way, the data obtained was de following:

- 87 patients were attended to, making a total of 116 avulsed teeth;

- The time of extra-alveolar permanence ranged from 30 minutes $(13,8 \%)$ to 96 hours $(1,1 \%)$;

- The most utilized means for the conservation of the avulsed dental elements was milk (43,5\%);

- The kind of splint most used was a variety with compound resin (50,0\%);

- The teeth most affected were the upper central incisors (72,4 \%);

- Avulsion occurred most frequently in the age range between 8 and 10;

- Predominance of the male sex $(60,9 \%)$ in relation to that of the female (39,1\%); 
- $81,6 \%$ of the patients were white, and $17,2 \%$ were black, while $1,2 \%$ were Asiatic;

- The accidents occurred most frequently in the fall;

- $21,9 \%$ of the accidents had more than 1 avulsed tooth.

Confronting this information with the pertinent literature, one can observe that our data is similar to that which is contained in the studies on avulsion and replantation, and conclude that in the last 5 years, the extent of the layman public's knowledge in relation to the conservation of avulsed teeth has evolved quite a bit, although among professionals in dentistry, the concept of immediate replantation predominates, regardless of the time of extra-alveolar permanence or the means of conservation utilized.

Endodontic therapy performed with intra-canal calcium hydroxide dressing, over the period of 1 at 2 years, proved to be efficient in the prevention of external inflammatory reabsorption. 